\title{
Aristokrater, kvinner, kunnskap og makt - Vik fra romertid til vikingtid
}

\section{Innledning}

De to gårdene Hove og Hopperstad i Vik i Sogn er hovedarenaer for denne fortellingen. De peker seg ut med henholdsvis svære gravminner reist i eldre jernalder på Hove og rikt gravgods i flere graver fra yngre jernalder på Hopperstad. Denne tilsynelatende kronologisk betingete skjevheten i kildematerialet forte i sin tid til at det ble foreslått at maktforholdet mellom de to storgårdene endret seg gjennom jernalderen (Lidén 1996), og at Hopperstad i løpet av vikingtid kan ha gjort den gamle høvdinggården Hove rangen stridig når det kom til makt og velstand (Fett og Fett 1951). Forholdet mellom de to storgårdene er et tema som fremdeles engasjerer både lokalmiljø og fagmiljø, og er slik sett utgangspunktet for denne undersøkelsen. Hovedfokus i denne artikkelen er Hopperstad, som utmerker seg med en rekke svært velutstyrte kvinnegraver. Gjennom disse gravene møter vi gårdens kvinner og aspekter ved livene de må ha levd. Kvinnerollene blir videre belyst gjennom den norrøne æreskodeksen slik den er blitt tolket med utgangspunkt i islandske ættesagaer (Sørensen 1993). I vår sammenheng leses æreskodeksen - etter en diskusjon - som rammeverk for forståelsen av vikingtidens sosiale kjønn og rettesnor for begravelser av samfunnets overklasse. Åpnet samfunnets normer for at kvinner som de vi møter på Hopperstad, kunne bygge opp gården til et nivå der de kunne utfordre den gamle høvdinggården? I så fall, hvilke omstendigheter lå bak og/eller hvilke egenskaper var det disse husfruene hadde som satte dem i stand til å slå seg fram i et rimelig mannsdominert samfunn?

\section{Bakgrunn}

Lokalstudier kan ofte kaste et klarere lys over hendelser, prosesser og ikke minst mennesker enn oversikter gjør. Gården var samfunnets grunnenhet i jernalderen. Den er liten nok til at vi får en viss oversikt og føler vi kommer de enkelte generasjonene inn på livet, men ofte stor nok til at mange ulike aktiviteter og aspekter ved livet kan belyses herfra. Gården representerer slik sett et nedenfraperspektiv, det helt lokale, der menneskene levde sine hverdagsliv. I vikingtid var den også stedet der gårdens folk ble begravet. For oss blir gården prismet vi ser individene gjennom. 


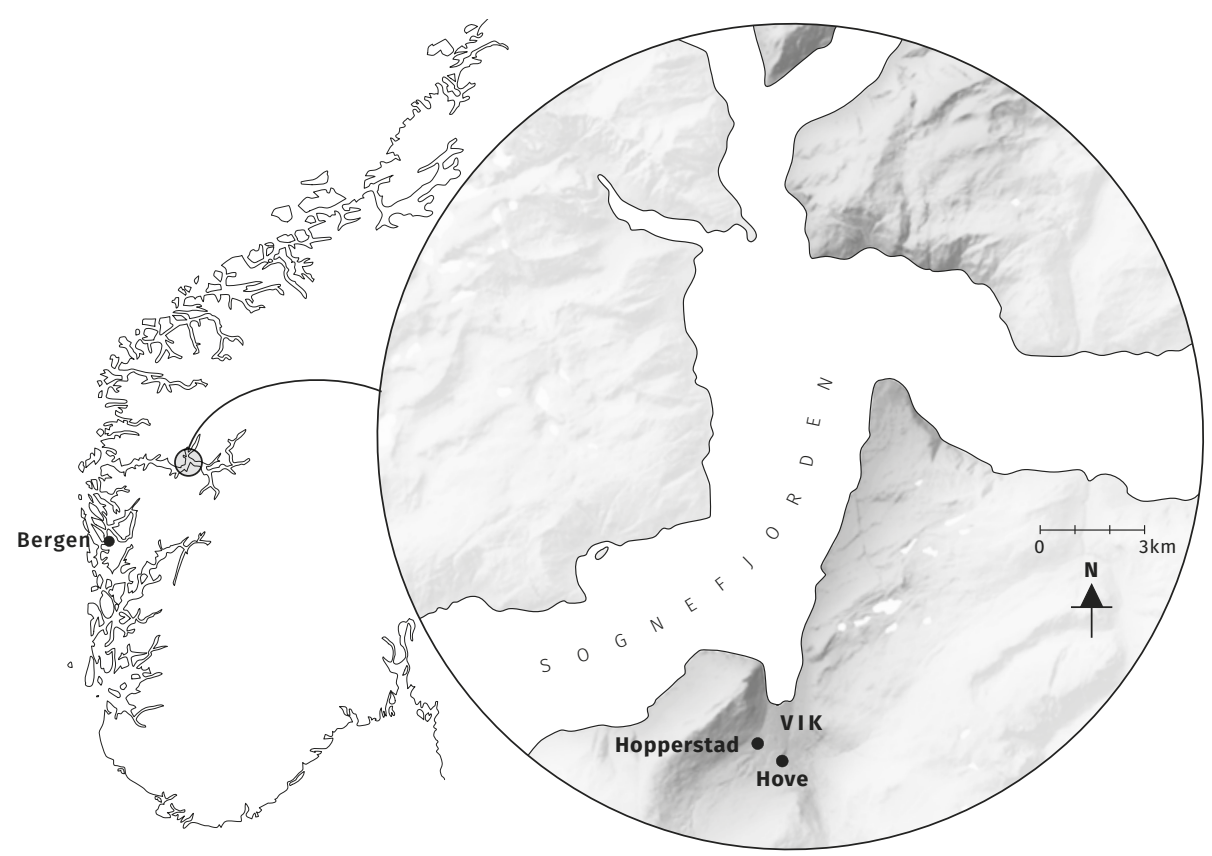

Figur 1. Vik i Sogn. Illustrasjon: Per Bakken. Kartgrunnlag: Statens kartverk.

Bygda Vik ligger sentralt i Sogn, den sørligste halvdelen av dagens Sogn og Fjordane fylke (se kart figur 1). Den dype 20 mil lange Sognefjorden deler Sogn i to på langs, mens fjell danner grenser mot nabolandskapene i nord, øst og sør. I vest åpner fjorden seg mot verden. Dette avspeiles særlig i vikingtidsmaterialet, hvor funn med opphav på øyene på den andre siden av havet er svært rikt representert.

Her er tallrike spor etter førhistorisk bosetning, ikke minst fra yngre jernalder, med gårder i lavlandet og gode vilkår for beitebruk i fjellområdene (Bødal 1998:88). Sogn og Fjordane er dessuten det fylket i Universitetsmuseet i Bergens distrikt som er best representert med funn fra yngre jernalder målt i kategorier som sverd, skålformede spenner, tekstilredskaper og «importfunn». Bygda Vik er en av de vestnorske bygdene med flest forhistoriske funn, særlig fra jernalder. Funnene viser til velstand og kontakter utad på flere gårder fra midten av romertid og framover. Da Eva og Per Fett skrev om forhistorien til Vik i bygdeboka fra 1951, karakteriserte de bygda som et sted der tiden utgjør en fjerde dimensjon (Fett og Fett 1951:52). Sigmund Bødal har i sin hovedfagsoppgave (1998) og i en senere artikkel (2000) karakterisert vikingtidens Vik som en tekstilbygd og en smedbygd. Til tross for mange funn og fornminner fra hele jernalder må kildematerialet til denne studien på et plan karakteriseres som noe ensidig; det er nesten bare graver og gravfunn. Disse er imidlertid blant jernalderarkeologiens viktigste og vanligste kildekategorier og brukes regelmessig til å belyse spørsmål varierende fra for eksempel handelskontakter til sosial status. 


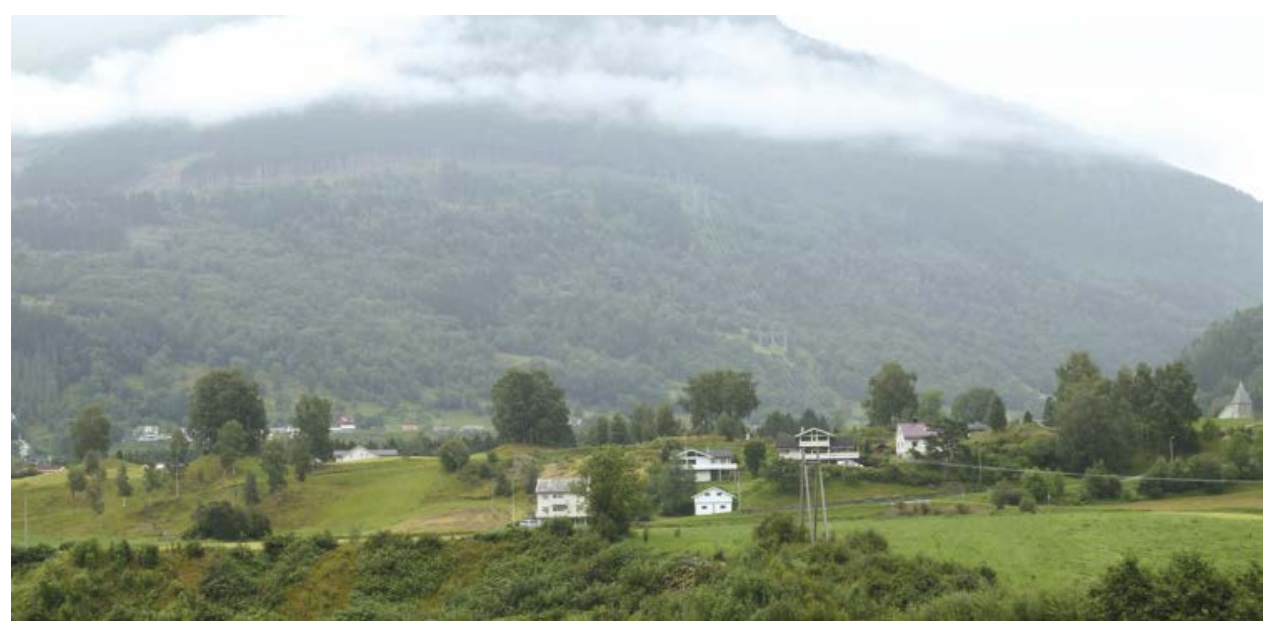

Figur 2. Hove sett fra Hopperstad. De store gravminnene ble plassert ytterst på terrassekanten, og har tronet over bygda siden. Nå vokser store løvtrcer på haugene. Foto: Alf Tore Hommedal, Universitetsmuseet i Bergen.

I denne artikkelen drøftes først og fremst vikingtidsfunn fra Hopperstad. Blant de ni yngre jernaldergravene som er kjent fra gården, er seks rikt utstyrte kvinnegraver, fem av dem trolig båtgraver. De forteller historier om mektige kvinner gjennom hele yngre jernalder.

Grunnlaget for vikingtidens samfunn ble lagt i de foregående periodene. Noen av de mest imponerende sporene i dagens landskap finnes nettopp på gården Hove, som ligger på en av de øverste terrassene i bygda. Her ble det i løpet av yngre romertid/folkevandringstid oppført minst ti store hauger, varierende i størrelse fra ca. 15 til ca. $35 \mathrm{~m}$ i diameter og inntil $4 \mathrm{~m}$ høye - i dag.

Eva og Per Fett (1951) pekte ut Hove som høvdinggården i eldre jernalder, mens Bjørn Ringstad (1987:239) kaller den et «storhaugsentrum av første rang». I begge tilfeller ligger det $i$ kortene at dette var bygdas maktsentrum i eldre jernalder.

De eldste gravene i disse haugene fulgte en nokså monoton branngravskikk med (som vi ser det) enkle gravgaver (figur 4), ofte av bein (Fett 1944; Dommasnes og Hommedal 2016; Dommasnes 2017) og uten våpen. ${ }^{1}$

Etter hvert kom andre skikker inn. De nye gravene, med glass, smykker og ikke minst kampvåpen, representerer et markert brudd med den eldre gravskikken, og viser gjennom gravgavene for første gang på flere hundre år klare kontakter med sørligere deler av Europa. Da de yngre gravene fantes i utkanten av haugene, må en anta at de alle var sekundærgraver. Denne nye typen gravgaver skulle bli retningsgivende for gravskikkene blant de høyere lag av samfunnet i Norge fram til kristen tid. 


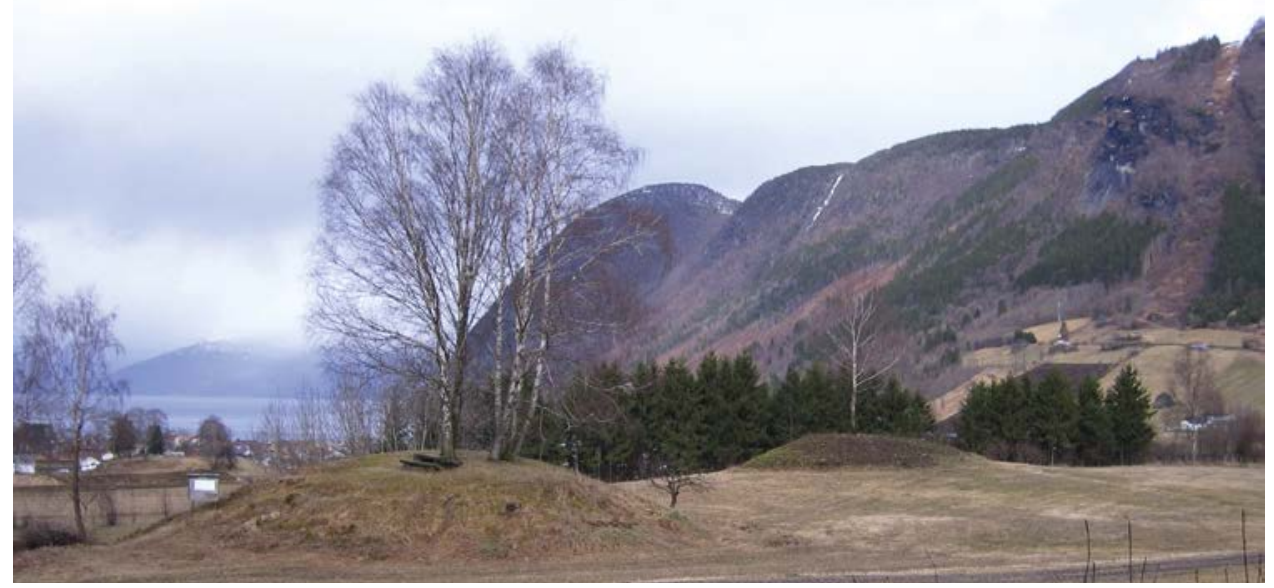

Figur 3. I løpet av yngre romertid/folkevandringstid ble det på Hove oppført minst ti store hauger, varierende $i$ størrelse fra ca. 15 til ca. $35 \mathrm{~m}$ i diameter og inntil $4 \mathrm{~m}$ høye-i dag. På flaten innenfor skal flere mindre vikingtidshauger ha ligget. Foto: Alf Tore Hommedal, Universitetet i Bergen.

\section{Yngre jernalder: Hopperstad og Hove}

Mens vi altså kjenner mange graver fra eldre jernalder på Hove, kjennes bare et keramikkskår og en korsformet spenne fra 4-500-tallet på Hopperstad. Det er imidlertid funnet ni graver fra yngre jernalder på gården, derav tre fra merovingertid, en periode som ellers er sparsomt representert på Vestlandet. Alle gravene er fra lokaliteten Haugateigen (figur 5). Det er bemerkelsesverdig at bare to graver (de med minst utstyr) hadde haugdekke. Resten

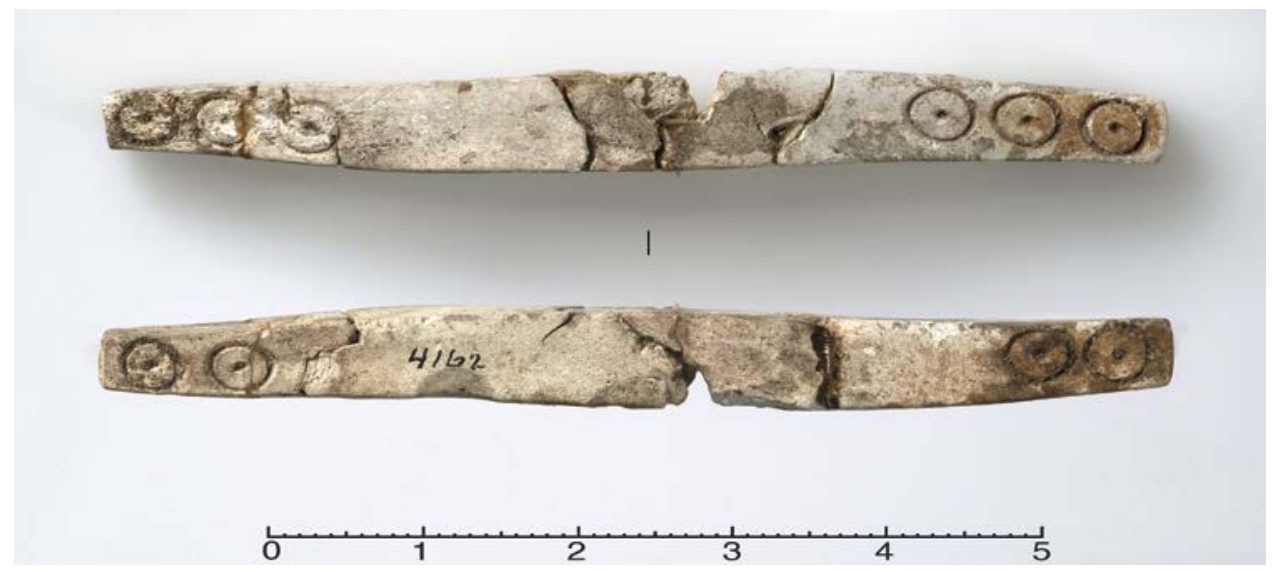

Figur 4. Spillebrikker av bein fra en av de eldre jernaldersgravene på Hove (B4162).

Foto: Svein Skare, Universitetet i Bergen. 


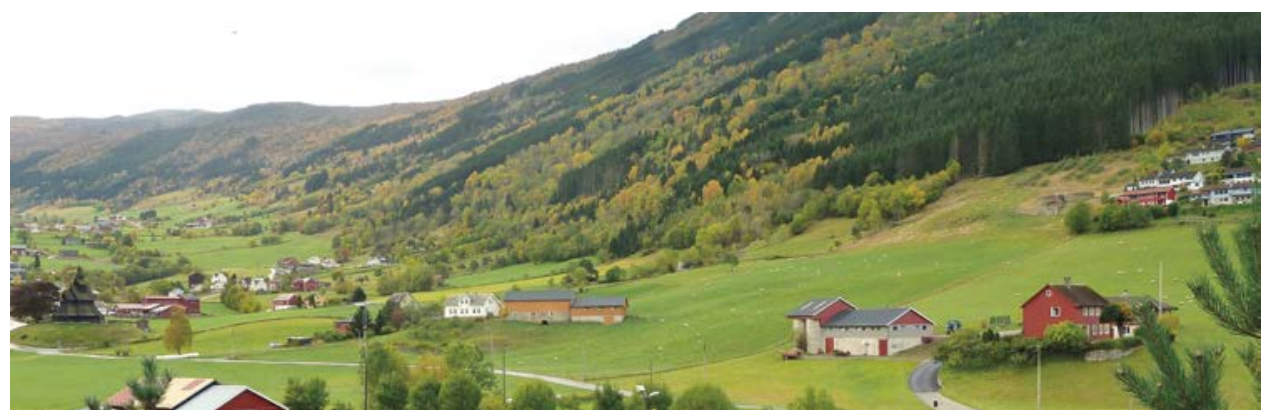

Figur 5. Hopperstad. Haugateigen der gravene fra yngre jernalder ble funnet, helt til høyre $i$ bildet. Hopperstad stavkirke lengst til venstre. Foto: Alf Tore Hommedal, Universitetet $i$ Bergen.

manglet synlig overflatemarkering. Hele seks ser ut til å ha vært båtgraver - det er vanskelig å være helt sikker, da klinknagler i bakken i noen tilfeller var omrotet og spredt. To tredjedeler - seks graver - var kvinnegraver, ${ }^{2}$ derav fem svært velutstyrte, datert fra åttende til tiende århundre. De tre mannsgravene, hvorav én er usikker og en annen en mulig dobbeltgrav for to menn, må karakteriseres som enkle, selv om iallfall dobbeltgraven var en båtgrav. ${ }^{1}$

På Hopperstad forteller altså rester av eldre gravfunn og yngre jernaldergraver (som også delvis var forstyrret) om en jevn utvikling fra folkevandringstid og framover, med økende rikdom jo lenger ut i vikingtid vi kommer. Det er ingen ting som tyder på at det gikk dårlig på Hopperstad selv om mennene er lite til stede i kildematerialet - snarere tvert imot.

Også på Hove ser det ut til å ha blitt anlagt nye graver i yngre jernalder. Elleve mindre hauger skal ha ligget på terrassen innenfor storhaugene fra eldre jernalder. Dessverre ble disse mindre haugene fjernet på 1800-tallet, men det som er bevart av funn, viser til vikingtidsbegravelser med våpen, smykker, hesteutstyr og redskaper til mange slags bruk, blant annet tekstilredskaper. De vitner om både kvinne- og mannsgraver som før de ble ødelagt, gjerne kan ha blitt oppfattet som velutstyrte. Et drikkehornbeslag kommer fra Irland (figur 6). Samlet sett ser det ut til at Hove-folket fremdeles må ha hevdet seg godt i lokalsamfunnet.

Hva forteller gravene og endringene i gravskikk ellers om religion, ideologier og samfunn? Storhaugene fra eldre jernalder framtrer i seg selv som maktsymboler. De vitner først og fremst om makt over ressurser - jord, byggemateriale, dyr og mennesker. Det er fristende å tenke seg at disse monumentene representerer herskerættene, eller aristokratene (Helms 1998) i høvdingdømmer, kanskje knyttet til en tidlig fase med eiendomsrett til jord (Grønnesby og Heen-Pettersen 2015; Dommasnes og Hommedal 2016).

Ved å begrave sine døde i svære hauger bygd av jord fra gårdene deres ble det skapt dype bånd til gården - odelen ble etablert. Med «odelshaugen» som arena blir det nærliggende å tolke de «nymotens» gravene satt ned i eldre hauger som vitnemål om

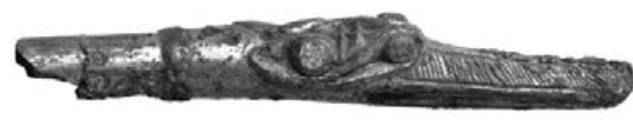

Figur 6. Irsk drikkehornsbeslag (B5551f) fra en av de utpløyde vikingtidsgravene på Hoveterrassen. Foto: Olav Espevoll, Universitetet i Bergen. 
ættens hjemvendte krigere og fremmedartede hustruer, inspirert av ritualer og verdier kvalitativt forskjellige fra forfedrenes.

Det har vært foreslått at en overgang fra et kollektivt samfunn til større vekt på individet var et vesentlig element $i$ endringsprosessen av skandinaviske samfunn fra eldre til yngre jernalder (for eksempel Herschend 1993; Hanisch 2001; Hedeager 2011). Det er lett å tenke seg at det er nettopp individet og individets ære som avspeiles i de noen ganger overdådig utstyrte gravene vi ser sakte, men sikkert dukker opp på Vestlandet fra midten av romertid og framover, til de blir rådende i yngre jernalder.

Kanskje kan endringer også finnes blant annet i kjønnsrollemønstrene. I de nye gravene er det nemlig tilsynelatende mye enklere å skille mellom kvinne- og mannsgraver enn det var i eldre begravelser. Det er all mulig grunn til å tro at ikke bare krigerrollen, men også husfruerollen, som i (vest)norsk materiale blir tydelig iallfall fra folkevandringstid, er blitt formet i møter med Europa, der den var vel kjent (se for eksempel Koch 1997), og hvor The Lady with a Mead Cup (Enright 1996) lenge hadde vært en institusjon i germanske krigerfølger. Krigerrollen på sin side ble en alternativ mannsrolle primært knyttet til mannens unge år. Samlet sett kan en kanskje si at de nye verdisettene åpnet for mer dynamiske samfunn og større fleksibilitet for individene. De formet selvfølgelig også kvinners liv, menns syn på kvinner - og kanskje kvinners syn på menn?

Rammen rundt folks liv var i vikingtid fremdeles gården. Gården var eiendom, hjem, arbeidsplass, boplass for husholdet og besøkende. Beboerne var gårdens eiere med familie og ofte litt fjernere slekt, kanskje slaver og midlertidig arbeidshjelp, det være seg i slåttonn, slaktetid eller i forbindelse med hus- eller båtbygging. Trolig var det slik at alle typer arbeid, ikke bare det som hørte til selve gårdens årssyklus, fant sted her. Det samme gjaldt formodentlig det sosiale liv: overføring av kunnskap mellom voksne og barn, religiøs kult, fester og begravelser. Både selve gravminnet og gravgodset blir dermed nær knyttet til (begrepet om) gården. Vi - arkeologene - har faktisk oppfattet sammenhengen som så nær at gravfunn har vært brukt som det helt sentrale kildematerialet for en lang rekke bosetningsstudier (Fett og Fett 1951; Straume 1962).

Selv om menneskene vi møter i yngre jernalders graver, nok har tilhørt bygdas mer privilegerte, vil tilnærminger med utgangspunkt i gården og enkeltindivider bidra til perspektiver som ofte savnes både i historiske og arkeologiske framstillinger. Verden ser forskjellig ut avhengig av ståstedet. Den som holder til i sentrum for begivenhetene, ser ting annerledes enn provinsboeren, den rike annerledes enn den fattige, kvinner annerledes enn menn (se for eksempel Harding 1991). Dette er utgangspunkt for det vi vanligvis omtaler som ståstedsteorier (engelsk: standpoint theories). Disse teoriene står alle i gjeld til marxistisk/sosialistisk tenkning. I utgangspunktet er slike teorier politiske og handlingsrettede. Det forhindrer imidlertid ikke at de også er utmerkede redskaper til å identifisere skjevheter blant annet i fortidige samfunn. Innenfor moderne arkeologisk forskning er de nyttige redskaper for den som søker å se verden fra ståstedene til grupper som ikke hadde makt, og/eller de som hadde mindre makt, for eksempel kvinner (feministisk teori) eller befolkninger i den ikke-vestlige verden (postkoloniale teorier) (se for eksempel Harding 1991, 1998; Hartsock 1998; Sweely 1999; Harding 2004). De inspirerer til diskusjon om maktens mange former, og minner oss om at makt, og hvem man kan ha makt over, er relativt i forhold til klasse, kjønn og roller. Slike utgangspunkter gir ikke bare, eller nødvendigvis, en mer «korrekt» historieskriving, 
men definitivt en som er mer nyansert. For en forståelse av vikingtidssamfunnet er de nærmest uunnværlige.

\section{Ere, makt, arkeologi og sosiale kjønn}

Eresbegrepet slik det ble brukt i middelalderens islandske sagaer, er blitt inngående diskutert blant annet i en doktorgradsavhandling av Preben Meulengracht Sørensen (1993). I en viss forstand, hevdet han, var ære nært forbundet med makt, idet ære var uforenlig med ufrivillig avhengighet av andre (Sørensen 1993:144-146), men den var også nært knyttet til arbeid, og til framferd. En æreløs person ble ikke respektert av noen. En av grunnene til utvandringen fra Norge i vikingtid kan nettopp ha vært at ikke minst stormennene opplevde at deres ære ble utfordret når andre søkte å tilta seg makt over dem. Inger Storli er blant dem som antyder en slik forklaring, nemlig i forbindelse med at storgården Borg i Lofoten ble forlatt rundt år 900 e.Kr. (Storli 2006:239).

Idealene slik de er skildret/tolket av Sørensen, er utledet av sagaer nedskrevet i kristen tid i fristaten Island. Bare frie menn og kvinner kunne, slik Sørensen leste sagaene, ha æren i behold, og normsettene henholdsvis menn og kvinner måtte forholde seg til, var delvis ulike. For en mann var det alltid vanærende å oppføre seg kvinnelig, mens det under gitte omstendigheter kunne være mulig for kvinner å tre inn i mannsrollen (Helle 2001; Sørensen 1993:213). Forventningene varierte også med alder. Krigeren var først og fremst den unge mannen som dro ut i verden for å høste heder og ære. Senere skulle han etablere seg som bonde hjemme på gården og forsvare fred og orden. For kvinner var det omvendt. De hadde lite de skulle ha sagt så lenge de var unge og ugifte. Først som husfruer kunne de få makt og innflytelse og, ikke minst, ansvar.

Siden har Morten Hanisch anvendt æreskodeksen i sin hovedfagsoppgave «Fortellinger om ære?». Æren ble her oppfattet som «en langsom historisk struktur» (Hanisch 2001:23) som kan spores over tid fra romerske forfattere til islandske ættesagaer. Hos Hanisch ble æren et rammeverk for forståelsen av gravritualene i yngre romertid og folkevandringstid på Vestlandet. Forestillinger om ære ble forbundet med handlingsidealer og en gryende individualitet, særlig knyttet til krigerideologier, våpen og for kvinner, tekstilarbeid, alt innenfor rammen av eldre jernalders gravskikk.

Hans tolkninger forholdt seg dermed til en tid flere hundre år før de islandske sagaene ble nedskrevet. Han argumenterte likevel for at æresbegrepet vi kjenner fra islandsk vikingtid/ middelalder har eldre røtter i germanske samfunn, også i Vest-Norge. Jeg er enig i at det er fullt mulig å tenke seg at æresbegrepene vi kjenner fra Island, har sitt utspring i skandinaviske/norske forhold før rikssamlingen og bakenfor der igjen fra det europeiske kontinentet. Dette blir særdeles tydelig på Vestlandet, hvor det er ytterst få funn av våpen (her forstått som sverd) fra yngre bronsealder (Melanie Wrigglesworth, personlig kommunikasjon 2018) og bare ett i førromersk jernalder (Pilø 1989). Gravgodset i vestnorske graver fra eldre romertid, for eksempel i storhaugene på Hove, har stort sett vært hjemlige gjenstander av bein. Det er rimelig å tenke seg at våpengravene, som kom inn fra midten av romertid, reflekterer et møte med en fremmed våpenkultur som skulle prege våre samfunn stadig mer $\mathrm{i}$ århundrene fram mot vikingtiden (Dommasnes og Hommedal 2016; Dommasnes 2017).

I dette arbeidet er to aspekter ved vikingtidens æresbegreper av spesiell interesse. For det første gjelder det tids- og eventuelle kulturforskjeller mellom samfunnet hvor ættesagaene 
ble nedskrevet, samfunnet de antas å skildre, og samfunnet vi undersøker her: Er de islandske æresbegrepene relevante for forståelsen av begravelsesskikkene, og dermed samfunnet, i norsk vikingtid? Dernest vil jeg se på idealene i forhold til kjønn og kjønnsroller - det vi i dag kaller sosialt kjønn - og til makt.

Eren slik den diskuteres av Sørensen, handler om å leve opp til samfunnets idealer (1993:207-208). Brukt med forsiktighet kan ære etter mitt skjønn være et fruktbart utgangspunkt også for forståelsen av gravskikk. Det virker intuitivt riktig at når man ville minnes de avdøde, var det deres gode egenskaper og handlinger - æren - som ble framhevet, da som nå.

Debatten om ættesagaenes relevans for forståelsen av vikingtidssamfunnet har rimeligvis vært dominert av norrønfilologer, og et av de store spørsmålene har vært om sagaene slik de er overlevert gjengir de opprinnelige muntlige fortellingene og dermed avspeiler det islandske samfunnet de oppgir å skildre («friprosalæren»), eller om det er verdisystemet fra tiden da de ble nedskrevet, stort sett på 1200-tallet, vi møter her («bokprosalæren»). Profilerte talsmenn for de to retningene var på 1900-tallet blant andre den norske folkeminneforskeren Knut Liestøl (1929) (friprosa) og den islandske litteraturforskeren Sigurður Nordal $(1953,1957)$ (bokprosa). Holdningene til dette spørsmålet vil også ha betydning for hvordan man vurderer mulighetene for at ættesagaenes forståelse av ære preget andre skandinaviske samfunn i vikingtid og tidligere. I moderne tid har frontene vært mindre skarpe og oppfatningen helst at dette spørsmålet må vurderes for hver enkelt saga (Beyer og Beyer 1970:44-47). Sørensen (1993:327) formulerte sitt eget ståsted slik: «Eller det er den enkle erkendelse af, at vi ikke har anden historisk virkelighed end den, som den skrevne tekst giver os, og at vores opgave er at forstå, hvad den fortæller os». Det synes å være et fruktbart utgangspunkt.

Sørensen framhevet dessuten arkeologien, eksemplifisert ved Peter G. Foote og David M. Wilson's The Viking Achievement (1970), som en mulig vei til fornyelse av debatten, fordi den «(...) beskriver hele samfundet, både dets materielle og dets sociale, religiøse og æstetiske aspekter (...)» (Sørensen 1993:322).

Nå har nok arkeologiens framstilling av samfunnet endret seg noe siden Foote og Wilsons bok ble publisert. Et av de (relativt) nye elementene er kjønnsforskningen, eller «genderarkeologien», som i Norge begynte på 1970-tallet, først som et synliggjøringsprosjekt (Dommasnes 1976, 1982; Bertelsen mfl. 1987), senere med et feministisk ståstedsperspektiv (Dommasnes og Kleppe 1985). I løpet av vel førti år med arkeologisk kjønnsforskning er den blitt internasjonal (se for eksempel Conkey and Spector 1984; Harding 1986, 1991; Karlisch mfl.1997; Harding 1998; Butler 1999; Gilchrist 1999; Harding 2004; Fries mfl. 2007; Dommasnes mfl. 2010; Dommasnes og Montón Subías 2012; Torreira mfl. 2012) med utgangspunkt i mange forskjellige akademiske miljøer og med ulike innfallsvinkler til prosjektet (se også AGE 2018; FemArc 2018). De fleste av dagens tilnærminger har det til felles at de avviser generelle, «universelle» oppfatninger av kjønn. En av de mer fruktbare innfallsvinklene handler om «interseksjonalitet» (se for eksempel Brumfiel og Robin 2008; Arnold 2016), eller som vi kanskje heller ville si på norsk: alternative/overlappende identiteter. Poenget er relativt enkelt: En person kan ha flere identiteter, og disse kan skifte gjennom et livsløp. Ingen av identitetene er låst for alltid, og ingen er nødvendigvis forbeholdt et av de (biologiske) kjønnene alene.

Det vil si, slik er det i det store perspektiv. I de fleste samfunn er det likevel slik at mennesker som hovedregel kategoriseres etter biologisk kjønn, og at kjønnsroller defineres noe 
ulikt, eventuelt med ulike tyngdepunkter, for de (to) kjønn. Slik var det åpenbart i det islandske samfunnet som ættesagaene beskriver/ble nedskrevet i.

Selv om den islandske æreskodeksen nok hadde sitt hovedfokus på menn og menns framferd, får vi også inntrykk av hvordan kvinner skulle oppføre seg. Overleveringen om æren kan altså betraktes som vitnemål om hvordan man i middelalderens Island, og kanskje i vikingtidens Norge, oppfattet det vi senere har lært å kalle «sosialt kjønn» både for kvinner og menn. Dette var normer for hvordan de to kjønn (av overklassen) skulle oppføre seg. Mellom de to settene med normer lå tabuområder. Et interessant trekk ved denne ideologien er at den på enkelte områder var mer bindende for menn enn for kvinner, som under visse omstendigheter kunne overta mannsroller (Sørensen 1993:213; Helle 2001:141-146). Det skal vi komme tilbake til.

\section{Gården som arena for læring}

Gården er et fast referansepunkt for rollebeskrivelser både i lovverk og sagaer. Slik vi kjenner sagaene, og slik æreskodeksen ble diskutert av Sørensen (1993), opererte den med to tilnærmet komplementære kjønn og noe ulike krav avhengig av livsfase og kjønn. For den unge jenta av god familie var framtiden klar: Hun skulle bli husfrue, gjerne for en stor husholdning.

Det spørs imidlertid om ikke de unge jentenes tidlige innsats har vært en smule undervurdert av forskerne. Vel skulle jentene holde seg hjemme på gården uten å bidra til stor dramatikk i livet. Men noen lang barndom i vår forstand hadde de neppe. Barnearbeid kan nok ha vært regelen snarere enn unntaket (og kanskje en av grunnene til at vi har så vanskelig for å identifisere barnegraver med utgangspunkt i gravgods). Det er all grunn til å tro at jentenes ungdomstid nettopp ble brukt til utdannelse innen felter hun skulle/kunne ha ansvar for som husfrue, slik vi kjenner det fra kontinentet (se for eksempel Koch 1997:46-48; Gutsmiedl-Schümann 2014:421-426). For henne var gården den naturlige arena for både utdannelse og dannelse. Vokste hun opp på en gård med stor husholdning og mange ulike aktiviteter innen kvinnedomenet, ville nok det være et pluss på ekteskapsmarkedet. Men også på en noe mindre gård ville det være mangt å lære: konservering av mat, fordeling av ressurser, spinning og veving, for å nevne noen. Man kan til og med tenke seg at den kontinuerlige kontakten med gården ville gi de unge kvinnene et fortrinn framfor menn når det gjaldt å forstå de mange ulike aspektene ved gård og gårdsdrift.

Om hun selv valgte det, kunne husfruen ifølge Grágás (del II:152), ta ansvar for alt som foregikk innan stokks. Det inkluderte fjøs og husdyr, også på setra. I egenskap av husfrue rådet hun også over gårdens nøkler, og dermed over verdier, både forråd og eventuell kapital investert i løsøre (Wallén mfl. 1981). Som administrator av innendørsarbeidet måtte hun beherske alle disiplinene dette omfattet. Tekstilarbeid var en slik spesialitet. Økende forekomster av spinnehjul og vevsverd i kvinnegraver tyder på at denne virksomheten tiltok i omfang fra folkevandringstid og fram gjennom vikingtid, da seilet kom i bruk. Var mannen bortreist, kunne husfruen drive gården alene, og hadde vide økonomiske fullmakter. Som enke hadde hun enda større økonomisk frihet. Kort sagt hadde gifte kvinner vesentlig innflytelse på gård og økonomi. Det var et stort arbeidsfelt som krevde innsikt på mange områder. 


\section{Gravgaver og ære i vikingtidens Norge}

Kan vi etter denne gjennomgangen gå ut fra at æreskodeksen slik den kjennes fra middelalderens islandske ættesagaer også var i bruk i det Norge landnåmsmennene forlot? Og virker det sannsynlig at den skal ha vært styrende for vikingtidens gravskikker?

Smykker og våpen er blitt betraktet som sikre kjennetegn på hhv. kvinne- og mannsgraver fra vikingtid, og dermed også som markører for kvinners og menns (høye) status. Mer eller mindre eksplisitt er de forstått som symboler knyttet til vikingtidskulturens kjønnsroller i samfunnets øvre lag - den våpenføre bonden på mannssiden og den festkledde husfruen/vertinnen på kvinnesiden. Det samme gjelder utstyr til husholdningen, særlig til gjestebud og tekstilarbeid. Slik sett synes det helt rimelig å arbeide ut fra tanken om at det var nettopp den avdødes ære som ble markert i norske vikingtidsgraver. Vi arkeologene har tradisjonelt oppfattet gravgodset som vitnemål om arbeid og innsats, eller handling. Når fokus flyttes til æreskodeksen, legges en ny dimensjon til, og tolkningsmulighetene utvides fra arbeid til også å omfatte myndighet og ansvarsområder. Vi kan riktig nok ikke bevise at tenkemåten vi kjenner fra islendingesagaene, kom fra det norske vikingtidssamfunnet. Men vi kan si at det virker sannsynlig ut fra vikingenes historie, og at vikingtidens norske gravskikk synes å være kompatibel med disse æresbegrepene.

Kvinne- og mannsrollene var i utgangspunktet komplementære, sterkt markert og skilt fra hverandre. Likevel kunne kvinner på enkelte felter, som alt nevnt, ta over mannens arbeid og ansvarsområder, og faktisk tjene ære på det snarere enn å miste den. Relatert til vår problemstilling her gjelder dette for eksempel forholdet til gårdsdrift og økonomi i mannens fravær, som enke og som odelskvinne. Slike unntak er ikke bare kjent gjennom islendingesagaene og Grágás, men er også nedfelt i lovverket på norsk side. Hovedtendensen i Gulatingsloven er imidlertid klar: Rettslig sett sto menn sterkere enn kvinner (Helle 2001:141-145).

I noen tilfeller kan æreskodeksen bidra til å oppklare trekk i gravskikken som tidligere har vært dårlig forstått. Eksempler fra Hopperstad er «mannsutstyret» (skjebor, celt, ildstål) i kvinnegraven B4511 og en båtastrek (båtbyggingsredskap) samt en celt i B7761. Vektutstyr, også det funnet i B4511, og kjønn var lenge omdiskutert (se Stalsberg 1996). Nå forstår vi at dersom Hopperstad-kvinnene faktisk var ansvarlige for gården med alle aktiviteter som fant sted der, for eksempel handel og båtbygging, kunne denne innsatsen også bli anerkjent som ærefull og markert ved begravelsen.

Æren var samfunnets vurdering av individet. Ved begravelsen med tilhørende ritualer ble vurderingen endelig, som den avdødes ettermæle, offentlig, ikke privat (Sørensen 1993). Følger vi resonnementet videre, blir det også forståelig at det bare er voksne, frie menn og kvinner vi normalt finner begravelser til, ikke avhengige individer av ulike kategorier, eller barn. Mannens ære var det primære i den forstand at mannen og mannens rolle var dominant i det sosiale systemet. Men hans ære var også avhengig av oppførselen til kvinnene i familien. Hvis kvinnene, inklusive hustruen, ikke oppførte seg bra, gikk det ut over mannens anseelse.

Hvorfor da det ulike tallforholdet mellom kvinne- og mannsgraver? Det har i sin tid vært foreslått at kvinner i gårdsgraver i Sogn var slike som satt på odelsjord (Dommasnes 1976:134; 1979:110). Tilsvarende har Dagfinn Skre, med utgangspunkt i gravfelter i Ullensaker, foreslått at haugene ble bygget over den man tok arv etter, uansett kjønn (Skre 1997:44-49). Koblingen mellom grav på gårdens grunn og odel virker rimelig, selv om 
veien til odelsjord kunne være både lang og kronglete for kvinner (se for eksempel Helle 2001).

I yngre jernalder var smykkene hovedsakelig de ovale spennene, samt noen ganger «tredjespenner» av ulike slag. Søker man i gjenstandssamlingen til Universitetsmuseet i Bergen, finner man, ikke uventet, at sverd og spenner på ingen måte er sammenlignbare størrelser. Sverd gir 750 treff, derav 263 fra Hordaland, 405 fra Sogn og Fjordane og 82 fra Sunnmøre (som altså bare er et halvt fylke). ${ }^{3}$ Søk på ovale/skålformede spenner gir 88 treff, 22 fra Hordaland, 49 fra Sogn og Fjordane og 17 fra Møre og Romsdal. Ifølge disse tallene var det altså mer enn åtte ganger vanligere for menn å ha/begraves med tidens mest prestisjefylte våpen enn det var for kvinner å ha skinnende parspenner. Både sverd og ovale spenner er dessuten langt vanligere i Sogn og Fjordane enn i nabofylkene.

Bergljot Solberg (1985) har analysert et utvalg av yngre jernalders graver fra hele Norge. Hun delte, med referanse til lovverket, mannsgravene i tre grupper, med henholdsvis tre, to og ett våpen. Særlig for det 10. århundre er det stor grad av samsvar mellom landskapslovenes våpenkrav og utstyret i mannsgravene. Samlet er det ifølge Solberg bare $15 \%$ av mannsgravene i Vest-Norge som har tre våpen: sverd, spyd og øks. Gruppe to, med to våpen (hvorav ett kan være sverd), er bare litt vanligere, mens gruppe én med bare ett våpen - ofte øks eller spyd - uten sammenligning er den største.

Tilsvarende må man kunne tenke seg på kvinnesiden: Bare kvinner i de aller øverste sosiale lag hadde anledning til å bære ovalspenner, hvis ornamentikk kanskje refererte til privilegert kunnskap og/eller status som odelskvinne (Nissen Meyer 1935; Skre 1997) eller iallfall ansvar for gårdsdriften. Solberg (1985) definerte sin toppgruppe av kvinnegraver ved koniske eller ovale spenner pluss en tredjespenne, gruppe to hadde minst én konisk eller oval spenne, mens gruppe én ble definert ut fra minst fem perler og/eller tekstilredskaper.

For Vestlandet utgjør gruppen kvinnegraver med parspenner 16 \% (Solberg 1985:68) av kvinnegravene i materialet hun analyserte. På landsbasis er det anslått at antallet kvinner med ovale/skålformede parspenner begrenser seg til ca. 125 personer pr. generasjon, beregnet til vel 30 år (Kaland 2009:64). Betyr dette at det også var forholdsvis færre kvinner enn menn i samfunnets toppsjikt? Solberg finner at på Vestlandet var forholdet mellom kvinneog mannsgravene i gruppe tre, høystatusgravene (sverd eller ovale spenner), 1:3. For alle gravene samlet var det 1:4 (1985:75). Tidligere analyser av det samlede materialet fra Sogn har gitt forholdet 1:3 (Dommasnes 1976, 1982). Kvinnene på Hopperstad plasserer seg med sine gravgaver trygt i samfunnets toppsjikt, mens andelen kvinnegraver generelt bekrefter at kvinner i sin alminnelighet hadde noe lavere status enn menn.

Tekstilredskaper finnes jevnlig i kvinnegraver definert ut fra smykker, og i Sogn er det slik at jo finere smykker, jo flere tekstilredskaper synes det også å være. En tabell over «rike og velutstyrte graver i Sogn sikkert bestembare til kjønn», dvs. med parspenner eller våpensett, inneholder ni kvinnegraver. Med ett unntak ${ }^{4}$ inneholdt de fire eller fem ulike kategorier tekstilredskaper, noen ganger flere av hver kategori. I tjueen sikre mannsgraver var derimot tekstilredskapene kun representert med en kljåstein (fiskesøkke?), en saks og en usikker saks (smedsakser?) (Dommasnes 1976:appendiks V). For å finne kvinnene i fortiden må vi altså inkludere tekstilredskapene. 


\section{Hopperstad - en kvinnestyrt gård i yngre jernalder?}

Tre av de nettopp omtalte sikre sluttede funnene av graver med mange tekstilredskaper kommer fra Hopperstad i Vik. Til tross for senere forstyrrelser i noen av gravene framstår samtlige seks kvinnegraver fra Hopperstad som rikt utstyrte og med funn som synes å demonstrere både velstand og et vidt kontaktnett i øvre samfunnslag. Det ble funnet vevskeier i fem av dem, også i to hvor ingen smykker var bevart. Så mens den nye krigeren har stått i fokus i diskusjonen om Hove, skal vi nå fokusere på kvinner og kvinners arbeid og ære på Hopperstad, og spør igjen om ikke kvinnene kan ha hatt noe med den økte velstanden å gjøre.

To kategorier gravgaver særpreger kvinnegravene på Hopperstad, nemlig «importsaker» samt tekstilredskaper. Kvinnegravene viser, i motsetning til de få mannsgravene, til jevn kontakt med resten av verden, fra merovingertid og gjennom det 10. hundreåret. Noen av kvinnene synes å komme fra, eller ha hatt nære kontakter med, fjernere områder. Sent på 700-tallet ble en yngre kvinne gravlagt i båt (B9061). Smykkesettet hennes besto av to rektangulære bronsespenner av en type som var vanlig blant annet på Gotland (Ørsnes 1966:136-143; Jørgensen og Jørgensen 1997:3-44) mens tredjespennen var en uornert oval bronsespenne. Et kjede på godt over 70 perler av glass, rav og bronse har sannsynligvis hengt mellom parspennene. Tekstilredskapene var i dette tilfellet en håndtein (representert ved en liten krok), et spinnehjul og et vevsverd.

Vel hundre år senere ble to andre kvinner gravlagt like ved (B4637 og B9060). Begge bar ovale spenner. En av kvinnene ser, etter tannemaljen å dømme, ut til å ha vært et eldre menneske da hun døde. Hun hadde trolig brukt et irsk (bok)beslag som tredjespenne. Tekstilutstyret var omfattende i begge begravelsene, blant annet linkam (dvs. ullkam?), kroker til håndtein(?), spinnehjul, kljåsteiner av kleber, sakser, vevskei, et nålehus av bronse samt en syl som kan ha vært brukt til skinnsying (eller seil?). Her er altså mange sider av tekstil- og sømarbeid representert.

Omtrent fra samme tid eller litt tidligere enn den sist nevnte er nok en grav (B7761) med skålformede spenner, over hundre perler og denne gang en trefliket tredjespenne. Spinnehjul, vevsverd, to sakser og en kljåstein merket med et kors markerer tekstilhåndverket.

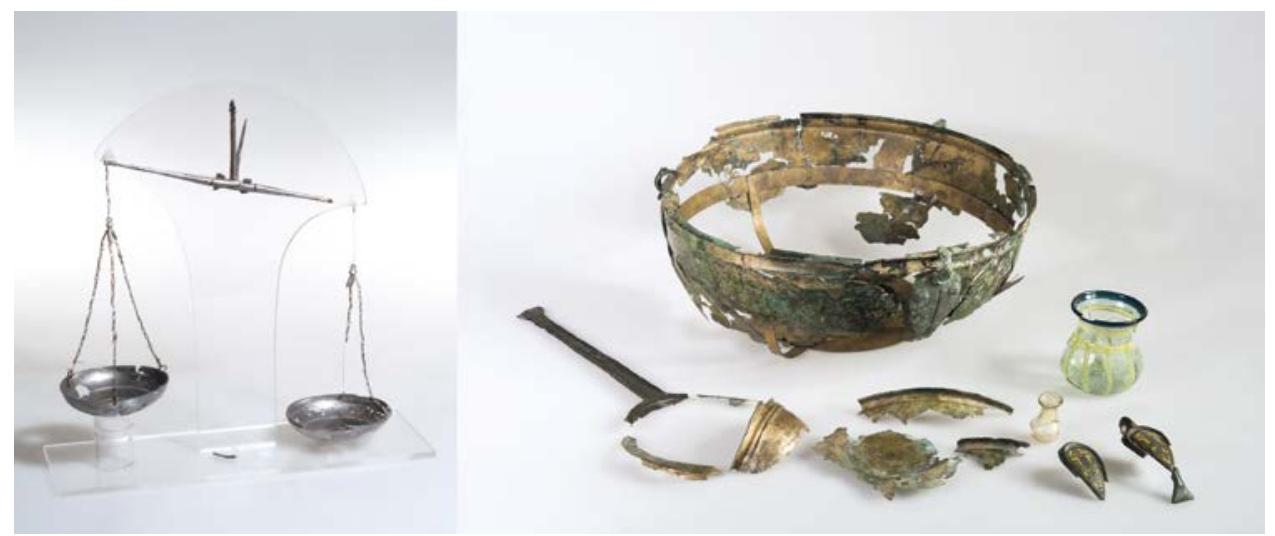

Figur 7. Hopperstad. Utvalg fra den «irske» brudens utstyr (B4511b). Foto: Svein Skare, Universitetet i Bergen. 
Samtlige kvinnegraver inneholdt altså tekstilredskaper. Den kanskje rikeste graven av dem alle, B4511, fra 10. århundre, har bevart to spinnehjul, et vevsverd og ni kljåsteiner til minne om tekstilarbeid. Her var dessuten ildstål, stekepanne, stekespidd og en av de få ranglene vi kjenner fra Vestlandet. Aller mest er likevel denne graven kjent for sin skålvekt med irske vektlodd, rester av tre ulike bronsekar og en øse/sil, et trespann med beslag av irsk bronse, samt to små glassbegre. En halv kufisk mynt var der også, samt rester av et skrin. Bortsett fra perler glimrer imidlertid smykkene med sitt fravær. Kjønnstilskrivingen er dermed basert på tekstilredskapene.

Andre funn fra kvinnegravene på Hopperstad er to nøkler, to bisler, en båtastrek (B7761) og to hvalbeinsplater (B4637 og B9060). Samlet gir dette inntrykk av godt over gjennomsnittet mektige husfruer med

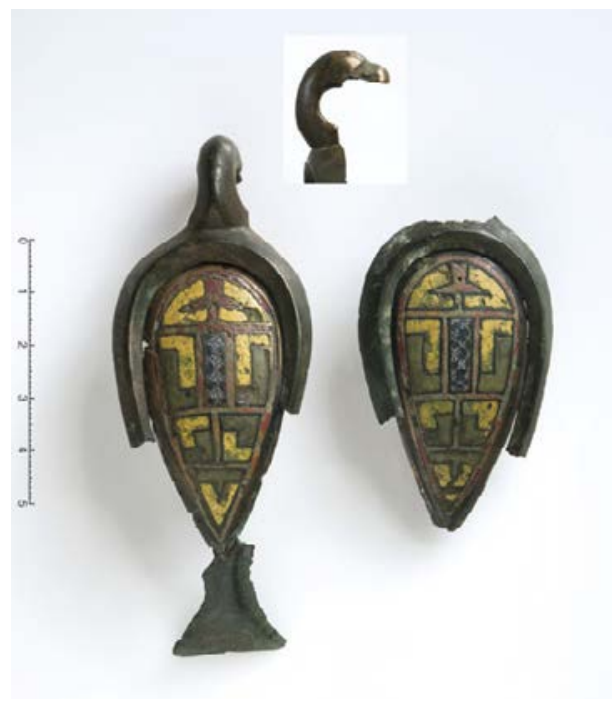

Figur 8. Hankebeslag fra et av karene $i$ graven (B4511b). Foto: Svein Skare, Universitetet i Bergen. gode kontakter til Østersjøen i sen merovingertid og senere til det kristne Irland. Det har vært foreslått at de to utenlandske kvinnene kan ha kommet til Vik som bruder, og at noe av utstyret i gravene er del av medgiften (Bødal 2000; Dommasnes og Hommedal 2016). Hvalbeinsplatene i to av gravene antyder kontakt/ allianser også med fornemme kretser i Nord-Norge. Inger Storli (2006:239-240) har foreslått at hvalbeinsplatene var Håløygslektas varemerke.

Bare én av kvinnene på Hopperstad ble begravet i haug, så vidt vi vet (B4381). Hennes gravgods var tilsynelatende enkelt: en vevskei og en celt. De fem andre vi kjenner til, ser ut til å ha blitt begravet i båt uten varig overflatemarkering, men med rikt gravgods. Det var sikkert heller ikke noe som ble hvem som helst til del.

Det er påfallende at kvinnegravene foruten å vitne om langveis kontakter er mye rikere utstyrt enn mannsgravene. En bør være åpen for muligheten av at gården kan ha vært på kvinnehender kanskje over flere generasjoner. Båtastreken i en av gravene (B7761) kan tyde på at hun som ble gravlagt der, også har stått for båtbygging, mens en annen av husfruene (B4511) hadde en skålvekt som antyder at hun kan ha drevet med handel (se ovenfor). I utgangspunktet hører verken båtbygging eller økonomi inn under kvinnesfæren, selv om lovverket som nevnt åpnet for delegering av økonomiske transaksjoner til kvinner, og langt på vei full råderett over egen eiendom for enker (Helle 2001:141-143). Det er fristende å mene at kvinnene vi møter her alt fra sen merovingertid av selv styrte gården og la grunnlaget for dens videre vekst og økonomiske suksess. Hvorfor det ble slik, vet vi ikke. 


\section{Tekstiler: råvarer og redskaper}

De mange ulike tekstilredskapene i kvinnegravene tyder på at i vikingtidens Sogn kunne tekstilarbeid være en både spesialisert og omfattende virksomhet som kan ha hatt egne bygninger for arbeidet og nedslagsfelt utenfor den egne gården. Det er ikke gjort moderne undersøkelser av tunområdet på Hopperstad. Men på gården Sæbø, som ligger på en flate litt lenger nede mot fjorden i Vik ble det i 2013 avdekket et grophus. Der ble det funnet perler, spinnehjul og vevlodd, som tyder på at huset har vært brukt blant annet til tekstilarbeid (Åstveit og Melvær 2013). Et tilsvarende grophus er tidligere undersøkt på Nes i Sogndal, på nordsiden av fjorden (Mortensen 1993). Slike funn antyder at tekstilproduksjon, kanskje i større skala, sto sentralt i midtre/indre Sogn. Da må både råvarer, utøvere, kontaktnett og transport ha vært tilgjengelige.

Både finere stoffer og seil ble gjerne vevd av ull. Det samme gjelder båtmannskapenes utstyr av klær og sengetøy. Ull er knyttet til husdyrholdet på gården, og husdyrene var kvinnenes område. På Vestlandet kan forholdene ha ligget til rette for at saueflokkene kunne gå ute store deler av året. Undersøkelser i vestnorske fjellstrøk har også vist intensivert bruk av fjellområdene i 7./8. århundre e.Kr. (Myhre og Øye 2002:177; Bender Jørgensen 2012).

Dermed var det grunnlag for en omfattende tekstilindustri basert på ull i vikingtiden, ikke minst i Vik (Bødal 2000:47). Den rikelige tilgangen på råvarer ble ekstra viktig etter at bruken av seil førte til en dramatisk større etterspørsel i yngre jernalder enn tidligere (Rabben 2002:68 med referanser).

Også tekstiler av lin kjennes fra vestnorsk vikingtid (Bender Jørgensen 1986; Lukesova mfl. 2017). Relativt hyppig forekomst av sigder i kvinnegraver (se for eksempel Dommasnes 1976) antyder at kvinner, til tross for at deres domene i prinsippet var innan stokks, også tok del i innhøstingsarbeid. Det er nærliggende å knytte sigden til innhøsting blant annet av lin. Linpollen, trolig knyttet til dyrking, er påvist blant annet på Vereide i Gloppen i Nordfjord, i kontekster datert til førromersk jernalder/eldre romertid (Kvamme 1997:236). Senere har det kommet flere til (Mehl og Hjelle 2016). En nylig undersøkelse av et utvalg graver med tekstilrester muligens av plantefibre har dessuten identifisert/bekreftet forekomsten av lin i seks yngre jernaldergraver i Sogn og Fjordane, derav en på Hopperstad (Lukesova mfl. 2017). Skal vi tro at linstoffer påvist i gravene fra Hopperstad (Bender Jørgensen 1986), ble vevd av hjemmedyrket lin?

Kvinnegravene som diskuteres i det følgende, inneholder alle et eller helst flere tekstilredskaper. Samlet er hele spekteret fra sigd (til skjæring av lin?), saks (blant annet til klipping av sauer?), linkam/ullkam, håndtein(-skrok), spinnehjul, vevskeier, kljåsteiner, synåler (nålehus) representert i funnene på Hopperstad. Dessuten en såkalt «vevreell» (til innslag i veven?) og en syl. Sylen kan muligens ha vært brukt i forbindelse med søm i lær eller i tettvevde, grove materialer som for eksempel seil.

Vevsverd og spinnehjul er blant tekstilredskapene vi ofte finner i jernaldergraver. Spinnehjul må vel antas å ha vært kanskje det aller vanligste tekstilredskapet. I gjenstandsdatabasen Unimus (2018) er det registrert 143 snellehjul/spinnehjul fra Sogn og Fjordane. I den andre enden av skalaen er nålehus av bronse. De må antas å ha vært forbeholdt de aller mest fornemme, som hadde overskudd til å befatte seg med finere søm. Det er registrert fire slike fra Sogn og Fjordane, herav to fra Sogn (Hopperstad i Vik og Målsnes i Balestrand).

To av kvinnegravene på Hopperstad mangler parspenner. Den ene gjelder den sene graven med de mange irske sakene. Denne graven er ikke undersøkt av fagfolk i felt, og det er 


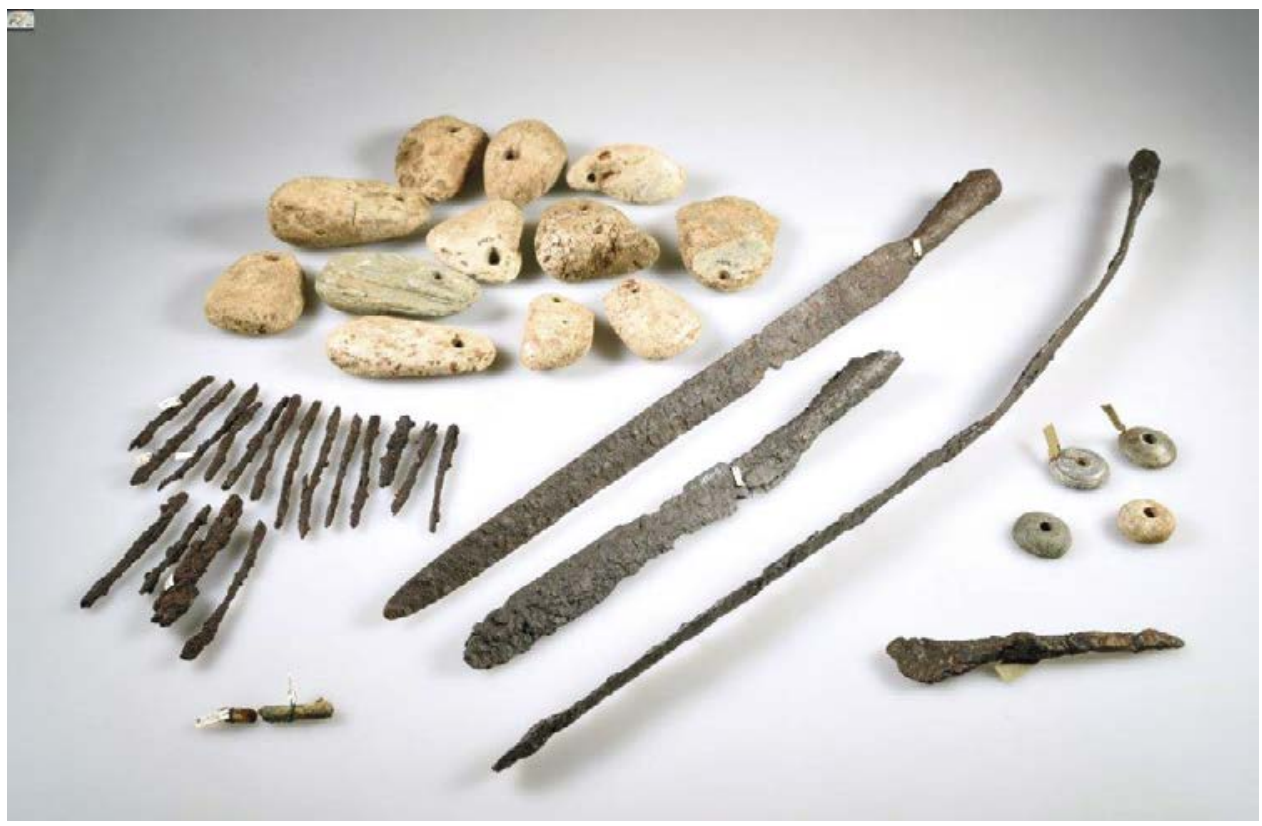

Figur 9. Samlebilde av et utvalg tekstilredskaper fra Hopperstad. Foto: Stine Rost Kronvang, Universitetet $i$ Bergen.

rimelig å tro at smykkene har vært der, men er kommet bort. Den andre kvinnegraven uten smykker er den eneste kvinnegraven i haug. Denne kvinnen hadde imidlertid et vevsverd. Søker vi igjen i gjenstandsdatabasen, nå på vevsverd/vevskei, får vi 57 treff når middelalder og funn fra andre distrikter er fratrukket. Førti treff er fra Sogn og Fjordane, tolv fra Hordaland og fem fra Møre og Romsdal (noen funn fra eldre jernalder er trolig med i antallet). Det forteller oss egentlig at vevsverd av jern var like eksklusive som ovale spenner, dernest at de, i likhet med sverd og ovale spenner, var langt vanligere i Sogn og Fjordane enn i nabofylkene.

De fleste vevsverd har trolig vært av tre eller bein. Vevsverd av jern bør sannsynligvis betraktes som mer enn et redskap. De synes også å symbolisere både kompetanse og ære, og bekrefter at kvinners posisjon, i likhet med mannens, kunne være avhengig av egen innsats, ikke bare av ætt og formell funksjon.

\section{Tekstilene og deres sosiale funksjoner}

Mens det er vanlig å finne tekstilredskaper, bevares naturlig nok selve tekstilene sjeldnere. Vestnorske tekstiler ble først systematisk undersøkt og satt inn i en større sammenheng av Lise Bender Jørgensen (1986).

Et av de fineste stoffene yngre jernalder kan by på, er krystallkypert av Birka-typen. I merovingertid finnes slike stoffer stort sett langs Østersjøen og i Vest-Norge. I vikingtiden er krystallkypert utbredt på Vestlandet i Norge, i Oseberg- og Gokstad-gravene samt i Birka, 
Hedeby og Kaupang (Bender Jørgensen 1986:174-175), og ellers spredt langs kysten, i nord til Trøndelag og i øst til Vestfold.

Samlet er seks vikingtidsgraver med krystallkypert funnet i indre del av Sognefjorden, fra Sogndal og østover. Merkelig nok er de alle kvinnegraver, to fra det 9. århundre og fire fra det 10. To av disse gravene er fra Hopperstad og tre fra Sogndal. I Aurland finnes nok en konsentrasjon av rike kvinnegraver, hvorav én (10. århundre) fra Vinjum hadde rester av krystallkypert. Til denne konsentrasjonen bør man kanskje, selv om det involverer en tur over fjellet, regne med to velutstyrte graver fra Voss, begge fra det 10. århundre. Her er det påvist krystallkypert $\mathrm{i}$ to graver, en kvinnegrav og en dobbeltgrav kvinne/mann (Bender Jørgensen 1986).

Produksjon av finere tekstiler har i litteraturen vært knyttet til storgårder. Ursula Koch har hevdet med utgangspunkt i tyske gravfelt fra Pleidesheim og Klepsau (Koch 1997) at vevsverdene var velstående og vel ansette kvinners gravgods. De symboliserte husfruenes kompetanse. Tilsvarende argumenterer Siv Kristoffersen (2000:135-136) for at vevsverdene representerte en høyt utviklet kunnskap og dermed definerte denne delen av husfruerollen i folkevandringstiden. Bender Jørgensen (1986:175-176) på sin side mener tekstilredskaper i kvinnegraver kan tolkes som «symboler på kvindernes status som producenter af en vigtig handelsvare». Det har også vært foreslått at finere tekstiler har kunnet inngå i allianser og gavebytterelasjoner (Kristoffersen 2000:135, 142 med referanser).

Tekstilenes mulige roller $i$ handels- og allianserelasjoner understreker tekstilarbeidets potensielle betydning i et større perspektiv. Det er på sin plass igjen å minne om at flere av Hopperstad-kvinnene hadde smykker og annet gravgods som peker utover, mot Gotland, Irland og Nord-Norge fra det 8. århundre og inn i det 10., og kan betraktes som mulige vitnemål om allianser for eksempel gjennom ekteskap.

Andre funn fra vikingtiden forteller at tekstilarbeid ikke utelukkende ble drevet på gården, men også har funnet sted på kaupanger. I Norge synes det å ha vært tilfelle på Kaupang i Skiringssal, som ser ut til å ha hatt en utstrakt tekstilproduksjon. Analyser av vevlodd og spinnehjul tilsier at her kan det ha blitt vevd tekstiler av både fine og grovere kvaliteter (Øye 2011:368). Også på den relativt nyoppdagede markedsplassen Bjørkum i Lærdal er det påvist grophus med funn av spinnehjul. Disse husene ser imidlertid ut til å ha vært lite solide, kanskje midlertidige strukturer (Ramstad 2011:46-47). Ingvild Øye (2016a:58) mener det her kan ha vært produksjon av (grovere) tekstiler i relativt stor skala. Morten Ramstad, som var ansvarlig for undersøkelsen i 2009, mener imidlertid at Bjørkums viktigste funksjon har vært som sosial møteplass (skeid) (Loftsgarden mfl. 2017; Morten Ramstad, personlig kommunikasjon 2018). Uansett er veien fra Hopperstad til Bjørkum både relativt enkel og kort. Det er derfor ikke usannsynlig at man kan ha etablert en vevebod på sin nærmeste markeds-/møteplass i sommerhalvåret - i så fall sikkert i konkurranse med mange andre gårder både i Sogn og på den andre siden av fjellet. Om husfruene selv møtte opp i en slik sammenheng, er mer usikkert. Det er heller ingen sikre indikasjoner på at handelssteder eller andre samlingsplasser generelt overtok gårdens rolle som det viktigste produksjonsstedet for tekstiler i norsk vikingtid. 


\section{Hvem vevde seilet?}

Et annet spørsmål er hva som skjedde da seil kom i bruk. Trafikken over Nordsjøen og for den saks skyld til kontinentet går lenger tilbake enn til vikingtid. Enten man ror eller seiler, krever sjøreiser spesielle tekstiler (jf. Bender Jørgensen 2005) om man skal kunne holde seg noenlunde tørr og varm. Det gjelder klær så vel som seil. Vi må derfor gå ut fra at produksjon av grove tekstiler beregnet til bruk på havet har vært vanlig på mange kystnære gårder i mesteparten av jernalderen. Det er imidlertid også klart at med de nye behovene som seil (og kanskje flere sjøreiser) førte med seg, må arbeidet med å framstille tekstiler både ha økt betydelig i omfang og ha blitt mer mangfoldig. Det har vært anslått at arbeidet med spinning av garn og veving av et seil alene ville ta ca. 8000 arbeidstimer. Produksjon av klær og utstyr til mannskap (og eventuelle passasjerer) er blitt anslått til ca. et år pr. person (Bender Jørgensen 2012:178).

Da seilet kom i bruk, på 700-tallet, måtte det derfor utvikles enda en ny ekspertise innen tekstilhåndverket, samtidig som omfanget av produksjonen økte dramatisk. Bender Jørgensen foreslo i 1986 at den etter hvert svært omfattende tekstilproduksjonen var organisert i et «forlagssystem», der «forleggeren» holdt råvarene og organiserte de lokale produsentene i distriktet. Senere har det vært hevdet (Rabben 2002) at ved overgangen til seilskip ble organiseringen av tekstilarbeidet og omsetningen av tekstilene overtatt av menn, et synspunkt som blir relativt ofte referert i litteraturen, men oftest uten større diskusjon av premissene for slutningen (Hellesøe 2006; Jacobsen 2008; Øye 2011; Bender Jørgensen 2012; Øye 2016b).

Anders M. Rabbens argumenter for at menn tok over særlig det tekstilarbeidet som hadde med seil å gjøre, er etter mitt skjønn uklare. Hovedargumentet, eller snarere en premiss, synes å være at dette (veving og omsetning av seil) var noe kvinner ikke var i stand til å organisere, «som bare menn kunne stå for» (Rabben 2002:68, 72, 103).

Dette ble utgangspunktet for en kategori «mannsgraver med tekstilredskaper» definert ved kombinasjonen av våpen og et eller flere tekstilredskaper. Funnkombinasjonene framstår stort sett som lite overbevisende. Med ståsted i den nye funnkategorien og med utgangspunkt i tidlig queer theory (Lesick 1997) mener Rabben å identifisere en gruppe menn som han mener kunne ha gått inn i rollen som entreprenører innen tekstilhåndverket uten å komme i konflikt med samfunnets normer. Men hvis det skulle finnes en kategori ikkelenger-mann i det norrøne samfunnet, hvorfor da lete etter den ved å bruke våpen - det som mer enn noe annet symboliserte maskulin ære - som kjennetegn? For den saks skyld burde man også diskutere om det er rimelig å anta at personer som ikke falt inn under den norrøne æreskodeksen, fikk en synlig begravelse med gravgaver i det hele tatt.

\section{Kompetanse - kunnskap}

Minst like viktig som argumenter ut fra våre tolkninger av materielle symboler er spørsmålet om hvem som kan ha vært best skikket. Det faktum at «våpengraver med tekstilredskaper» sjelden inneholdt mer enn ett eller to redskaper, tar Rabben til inntekt for at produksjonen var spesialisert: Noen kardet, andre spant, og noen vevde. Det kan så være. Også i graver forstått som kvinnegraver finnes ofte tekstilredskaper enkeltvis eller få sammen. Noen av disse funnene er ganske visst ufullstendige, men ikke nødvendigvis alle (jf. Solberg 
1985). Det er ikke svært problematisk å se slike funn som minner om hvor i prosessen denne personen hadde sin ekspertise.

Men hvis entreprenøren var den som samlet alle trådene, hvorfor skulle han bare minnes med et tilfeldig redskap fra prosessen, snart det ene og snart det andre? Når det gjelder Sogn, og trolig også andre steder, er regelen at i sikre, sluttede funn med parspenner finnes det mange tekstilredskaper i velutstyrte graver, trolig nettopp for å markere at her er hun som behersker hele feltet fram til ferdige tekstiler. Man kunne også tenke seg at vevsverdet alene kunne symbolisere noe lignende, $\mathrm{i}$ og med at det representerer det siste leddet i selve stoffproduksjonen. Vevsverd av jern må i alle fall ha vært langt mer eksklusive enn vi vanligvis har gått ut fra.

Som nevnt foran er det rimelig å tenke seg at store deler av unge jenters oppdragelse var en forberedelse til å fylle blant annet en rolle som øverste leder av tekstilarbeidet på gården. For de aller fleste, og ikke minst kvinner fra storgårder, var ganske sikkert tekstilarbeid en vesentlig del av oppdragelsen som forberedte dem til husfruerollen. Det var nettopp kvinnene som kunne koordinere en omfattende tekstilvirksomhet. De kjente alle arbeidsprosessene, inklusive tilsyn med dyrene, og kunne samordne arbeidet derfra til ferdig produkt. De hadde kunnskapen, lært gjennom erfaring fra barndommen av. Menn manglet denne kunnskapen, for, som filosofen Gilbert Ryle brukte minst én bok på å argumentere fram: «Vi lærer hvordan gjennom praksis. Kunnskapen som skal til for å forstå intelligente handlinger av et spesielt slag, er (en viss grad av) erfaring innen det relevante feltet» (Ryle 1949:41, 53, min oversettelse). Det er forskjell på å vite at og å vite hvordan. Å vite hvordan er basert på praktisk, kroppslig erfaring.

Slik kunnskap er også blitt kalt taus kunnskap (Polanyi 1966). Vi omtaler den dessuten ofte som tradisjonsoverført eller handlingsbåren. For argumentasjonen her er de ulike betegnelsene først og fremst interessante fordi de alle understreker at tekstilarbeid innebærer kunnskap som tilegnes gjennom erfaring, eller øvelse om man vil. I vikingtidens samfunn tilhørte akkurat denne typen erfaring knyttet til tekstilhåndverket kvinnesfæren så ettertrykkelig at det ble regnet som vanærende for frie menn å drive med slikt. For husfruen var imidlertid tekstilarbeidet bare en liten del av det hun måtte organisere. Husdyrhold, konservering, lagring og tillaging av mat samt det å arrangere gjestebud var andre bokstavelig talt livsviktige felter som lå under hennes ansvarsområde. Samlet ble dette en bred og variert erfaringsbakgrunn som må ha hatt betydelig overføringsverdi til andre felter.

Kvinner var heller ikke ukjente med handel og forhandlinger. Verken i landsens graver (for eksempel på Hopperstad) eller i vikingtidens kaupanger er skålvekter spesielt uvanlige å finne, heller ikke i kvinnegraver. Hele 17 \% av skålvektene som er funnet i Norge, er fra kvinnegraver (Stalsberg 1996 basert på Jondell 1974). I Birka var 32 \% av skålvektene fra kvinnegraver (Arbmann 1943; Stalsberg 1996), og i Rus ble vekter funnet i 22 \% av de skandinaviske kvinnegravene (Stalsberg 1996). På et slikt grunnlag kan vi kanskje også slutte at menn heller ikke var fremmede for å se kvinner i slike roller, spesielt ikke i forbindelse med kvinnenes egne produkter. At kvinner også i noen tilfeller kunne arve odelsjord, styre gården i mannens fravær eller som enke, og eventuelt representere sin ektemann på tinget, er alt med på å understreke at myndige kvinner ikke var enestående i vikingtidssamfunnet.

Vi har altså resonnert oss fram til at det var kvinnene som var best skikket til å ta seg av en jobb med å koordinere så vel som å utføre tekstilarbeid i stor målestokk. Overklassens 
kvinner var, i motsetning til menn, oppdratt med tanke på at de skulle styre en stor husholdning/gård, og hadde gjerne også gode kontakter. Det var i all enkelhet de som hadde den nødvendige erfaringen, kompetansen og nettverkene. Det ga dem makt.

\section{Makt over og makt til}

Makt opptrer i mange utgaver. Store monumenter oppfattes ofte som manifestasjoner av makt. Hove er blitt karakterisert som et maktsenter nettopp på grunn av storhaugene (Ringstad 1987). Dermed blir makt et sentralt tema her. Makt over noe eller noen ser annerledes ut fra toppen av samfunnet enn nedenfra (Harding 1991). Slik makt kan være de facto uten nødvendigvis å bli opplevd som makt, mens autoritet er makt som er anerkjent og legitim (Sanday 1974:190). Makt handler også om å få sin vilje igjennom selv om andre er imot (Giddens 1997:338).

Møter med Europa gjennom århundrene før vikingtid innebar kontakter med fremmede kulturer. Det er tydelig at kontaktene brakte med seg nye impulser til Vik. Møtene med andre samfunn, eller kanskje heller hjemkomstene, ble også møter mellom ulike verdisystemer (se også diskusjon av høvdingbegrepet i Grønnesby og Heen-Pettersen 2015), og kom ganske sikkert til å handle blant annet om maktforholdet mellom gammelt aristokrati og nye våpenideologier. Når inntrykk utenfra kommer til, vil det som regel påvirke den etablerte sosiale dynamikken og skape rom for endringer.

I det hjemlige Vik var det nedarvet jord, odel og aristokratisk annerledeshet som opprinnelig ga makt og innflytelse. I et krigeraristokrati derimot utmerket heltene seg med sitt individuelle mot og ferdigheter. Siden ikke æren, heller ikke slektens, var vunnet for alltid, men var knyttet til individer og deres handlinger, måtte retten til den stadig fornyes og bekreftes. Dette ble i seg selv en impuls til bevegelse og endring, også sosial mobilitet. Det gjaldt trolig både kvinner og menn, hver på sine fronter. Og det omfattet de gamle ættene, som jo egentlig hadde startet hele prosessen.

Kanskje var ikke den individuelle selvhevdelsen spesielt populær blant aristokratene av den gamle skole. De hadde hatt makt i kraft av sin posisjon, og hadde mye å tape, mens ikkearistokratene så nye muligheter i en tid da personlige kvaliteter og ferdigheter kunne gi stor uttelling, enten man nå var kriger eller for eksempel veverske. Den nye maktforståelsen må ha lignet mer på makt slik den er blitt problematisert av filosofen Nancy Hartsock. Hun har diskutert makt som kunnskap og evne til å gjennomføre endringer (Hartsock 1998:63-64). Dette potensialet finnes i alle lag av befolkningen, også hos de underprivilegerte. Slik makt nedenfra kjennes fra opprør, revolusjoner og mer fredelige protestbevegelser.

Nok et aspekt ved makt er at den har en tendens til å være kjønnet. I de fleste samfunn vi kjenner, har makt vært maskulin, og slik vi kjenner vikingtidssamfunnet, var det absolutt mannsdominert. Men vikingtidens samfunn var ikke bare kjønnsdelt, det var også lagdelt. Det er grunn til å tro at rang i mange tilfeller veide tyngre enn kjønn. Fire av de seks kvinnene 
vi kjenner fra Hopperstad, bar parspenner. Den siste, med det irske utstyret, må ganske sikkert også ha vært av en rang som tilsa et slikt smykkesett. Hvis jeg skulle mene noe om det, ville jeg tro at også kvinnen begravet i haug med et vevsverd opprinnelig bar smykker. Som medlemmer av toppsjiktet i samfunnet ville disse kvinnene ha makt over (mange) menn og kvinner av lavere rang. Men de opplevde nok også dobbeltheten ved å høre til i samfunnets toppsjikt samtidig som de var underlagt menn på grunn av sitt kjønn.

Kanskje hadde iallfall den «irske» husfruen et maktpotensial nettopp i kraft av sitt kjønn og kombinasjonen av roller. I hennes gravgods fantes to gjenstander som er blitt assosiert med overnaturlige krefter, nemlig en såkalt rangle og et redskap som inntil nylig gikk under benevnelsen stekespidd. Neil Price foreslo i 2002 at stekespiddene kanskje heller var volvestaven som tidvis er omtalt i skriftlige kilder (Price 2002). Dette forslaget ble fulgt opp av Eldar Heide, som påpekte at skaftet på mange slike spidd/staver er utformet slik at det kan minne om en håndten, som igjen har vært knyttet til trolldomskunster (Heide 2006). Slik makt kunne ramme mennesker. Ranglene vet vi enda mindre om, men det har vært foreslått at de ble brukt til å skremme bort onde makter (Petersen 1951). I distriktet til Universitetsmuseet i Bergen er det bare kjent tre rangler, derav to fra Vik (Hopperstad og Hove).

Den norrøne æreskodeksen, eller beskrivelsen av det sosiale kjønn i samfunnets toppsjikt som (kanskje) ble utviklet gjennom de tidlige kulturmøtene, fant en slags balanse mellom gammelt og nytt $\mathrm{i}$ at den lot den unge mannen vinne ære gjennom reiser og krigerferdigheter, mens den eldre utøvde makt og myndighet på sin gård (Sørensen 1993). Så var det jo praktisk at både æreskode og lovverk åpnet for at kvinner i dette mannsdominerte samfunnet om nødvendig kunne overta noen av mannens roller eller til og med arve jord. Det var tross alt til ættens beste.

Det er kvinnene på Hopperstad vi er blitt kjent med gjennom gravene; det er deres graver som har det rikeste utstyret. Som nevnt har det vært foreslått at kvinnegraver på gårdens innmark representerer kvinner som har arvet (odels)jord og dermed kunne styre gården. Dette ligger godt innenfor de mulighetene som fantes ifølge skriftlige kilder. I antall representerer slike graver ca. en fjerdedel til en tredjedel i vikingtid (Dommasnes 1976, 1982; Skre 1997). Hovedregelen var at odelsjord ble arvet på mannssiden (Helle 2001), men på grunn av kriger og mange sjøreiser kan man vel tenke seg at mannefallet over tid har vært stort, slik at kvinner kom til. Dominansen av kvinnegraver på Hopperstad kan tyde på at det har vært tilfellet her. Det må imidlertid ikke glemmes at det også må ha vært menn på gården. Tre eller fire av dem har vi graver etter, to enkeltgraver og en mulig dobbeltgrav i båt. Vi vet lite om bakgrunnen til Hopperstads kvinner, bortsett fra at noen av dem ser ut til å ha kommet langveisfra. Her er foreslått Gotland, Nord-Norge og Irland. Ut fra det vi kan lese av funnene, vil jeg tro de alle har kommet fra miljøer der de bør ha fått førsteklasses utdannelse innen feltene forvaltning, gjestebud og tekstilarbeid. Dette synes å bli bekreftet av kvantiteten og kvaliteten av innholdet i gravgodset deres, de mange tekstilredskapene, samt den sentrale plasseringen på funnkartet for tekstiler av Birka-typen. I sum viser det nemlig at de - kvinner i en mannsdominert verden? - har hatt kontakter i sentrale miljøer både innen- og utenlands.

Grunnlaget kan ha blitt lagt med en husfrue fra Gotland. Senere kan det ha vært giftermålsallianser både med Håløygætta og med Irland. Denne siste husfruen hadde med seg bronsekar i samme stil som tilsvarende kar fra blant annet Oseberg, Gausel og Myklebost på Eid i Nordfjord (Bakka 1993). Hun kom altså med et utstyr som kan assosieres med 
aristokratiske miljøer både i hjemlandet Irland og i Norge. Fruene til Hopperstad hørte ganske enkelt til i samfunnets høyeste lag, både de som måtte være født på gården og de som ble giftet dit. De sistnevnte har sikkert også brakt med seg erfaringer og kunnskap som utvidet referanserammene for gårdens folk. Det samme gjelder Hopperstad-folkets egne reiser over havet, som de mange irske gjenstandene fra gården vitner om.

En ikke fullt så holdbar vare som gjenstandene var den levende fangsten vikingene trolig brakte med seg i form av mennesker tatt til fange i fremmed land og forte til storgårder blant annet i Sogn som slaver (om slaveri i Norden, se Iversen 1997; Brink 2012). Slaver var ikke nødvendigvis uten kunnskap og ferdigheter. Tvert imot - de kom nok fra alle lag av folket. Noen var trolig prester og nonner røvet fra kirker og klostre, med både åndelige og praktiske innsikter. Slavenes sikkert mangfoldige talenter og ferdigheter må ha bidratt vesentlig til Hopperstads velstand og utvikling, også innen tekstilfeltet. Med ekstra arbeidskraft kunne husfruen utvide sin virksomhet. Kvinnelige slaver med erfaring fra ulike typer tekstilarbeid bidro utvilsomt med nye ideer og teknikker.

Slaver var ikke bundet av æreskodeksen. Dermed var mannlige slaver strengt tatt heller ikke i den sosiale kategorien «menn», og kunne eventuelt brukes i arbeidet med å veve seil og sjøklær, varer som nå var blitt svært etterspurte, men som kunne være både tidkrevende og tunge å produsere. Med et jevnt tilsig av arbeidskraft, som de mange funn fra Irland antyder muligheter for, kan tekstilvirksomheten ha blitt vesentlig utvidet og ha brakt enda mer gods og gull til gårds.

Kvinnenes maktbasis var husfruerollen. Den ga makt over mennesker og ressurser, og kunne åpne for personlig initiativ som gikk ut over gårdens grenser. En slik mulighet var det trolig Hopperstadkvinnene grep gjennom tekstilarbeidet. Det er vanskelig å finne noen grunn til å tro at de eller andre i deres situasjon ville velge å gi fra seg forvaltningen av et håndverk som ser ut til å ha vært en stor del av grunnlaget for deres suksess. Tvert imot. Kvinnene fra Hopperstad framstår som både dyktige, erfarne og selvbevisste, og forsto nok betydningen av å ha hånd om omsetningen av egne produkter. Innsiktene denne prosessen krevde, var det de selv som hadde, og makten som de fikk gjennom sin kompetanse blant annet innen tekstiler, ble ganske sikkert brukt til å skaffe seg kontroll over egne liv. Slik kan de også ha brakt gården de styrte, fram til en posisjon på høyde med den gamle høvdinggården Hove.

For alt vi vet, kan kvinnene som styrte på Hopperstad i oppgangstidene, faktisk ha fått støtte av kjønnsideologien, som ellers kunne holdt dem nede. Asymmetrien i æreskodeksen tillot som vi har sett kvinner i enkelte tilfeller å gå inn i mannsroller og til og med vinne ære på det - for eksempel ved å styre en storgård «like godt som noen mann». Da ble hun kanskje omtalt som «et drivandes kvinnfolk», «en som gjør en jobb så godt som en mann». Slike munnhell som roser kvinner ved å sammenligne med normen, mannen, lever i vårt språk den dag i dag. Som i så mye annet ligger det en dobbelthet i dette. Makt over mennesker hadde de nok, og over ressurser. Selv Hopperstads mektige husfruer hadde likevel neppe definisjonsmakt til å avgjøre hvordan de skulle omtales. Men æren vant de. 


\section{Noter}

1 «Moahaugane», også kalt Hovshaugane på Hove, gnr. 26 og Voll gnr. 27, er blitt delvis undersøkt i 1882 (Anders Lorange), 1913 (Haakon Shetelig) og 1923 (Johs. Bøe). Andre funn er framkommet mer tilfeldig. Museumsnumre fra Moahaugane: B98, B4047, B4049, B4161, B4162, B6691 I-III, B7490, B9127. AskeladdenID 110486.

2 Kvinnegraver på Hopperstad: B7761 ble ettergravd av Brage Irgens Larsen i 1926. B9059b-e og B9060 ble ettergravd/gravd av Per Fett i 1939, B9169 ble undersøkt av Eva og Per Fett i 1941. B4511 og B4637 er ikke faglig undersøkt. De kom inn til Bergens Museum i hhv. 1887 og 1890, og ble katalogisert av hhv. Anders Lorange og Gabriel Gustafson som samlede gravfunn. Jan Petersen (1940) omtalte B4511 som et samlet funn, mens Eva og Per Fett (1951) har argumentert for at funnet må være blandet, hovedsakelig fordi de mente at skjebor, celt og fyrstål måtte være mannsutstyr.

Mannsgraver: B9169, B10425 og muligens B9059 (sammenblandet funn fra eldre og yngre jernalder). Askeladden-ID for Hopperstad: 120299.

3 Middelalderen er skilt ut, men ellers skiller ikke databasen systematisk mellom arkeologiske perioder.

4 I Dommasnes 1976: Tabell over antatt sikre sluttede og fullstendige funn. På en skala med synkende verdi fra A til F var disse vurdert til kildeverdiene A og B. Det avgjørende kriteriet for kvinnegraver var her parspenner, for mannsgraver våpensett, som med ett unntak inkluderte sverd. Unntaket var en grav som inneholdt et sett parspenner samt spyd og øks. I dag ville jeg nok forstått den som en dobbeltgrav.

\section{Summary}

Aristocrats, women, knowledge and power - Vik from the Roman Age to the Viking Age This paper is inspired by local interest in the relationship between the two farms Hove and Hopperstad in the settlement of Vik on the Sognefjord in Western Norway, from ca. 200 AD through the Viking Age. Large burial monuments at the Hove farm indicate that this was the chieftain's farm in the early Iron Age, while only a few scattered remains of Viking Age burials are known.

At Hopperstad the situation is different. Nine burials from the late Iron Age are known from the farm. Six out of the nine are women's burials, most of them richly equipped, indicating that the women in question may have held important positions in the local community as well as a wide net of contacts in the upper strata of society. During the Viking Age, Hopperstad seems to have acquired a level of importance equal to that of Hove, perhaps even higher. The unusual ratio of female vs male burials seems to indicate that women were in charge of the Hopperstad farm during this process.

The main part of the paper is dedicated to a discussion of the mechanisms behind such an extraordinary social and economic advancement/success of the Hopperstad community under feminine leadership in a society where masculine dominance was the (almost) unquestioned norm. Potential factors addressed are the Norse code of honour, gender roles, and power. 


\section{Litteratur}

Arbman, Holger

1943 Birka: Untersuchungen und Studien. Die Gräber 1. Text. Kungl. vitterhets historie och antikvitets akademien, Stockholm.

AGE

2018 Archaeology and Gender in Europe. Elektronisk dokument, http://www.archaeology-gendereurope.org/, besøkt 4. september 2018.

Arnold, Bettina

2016 Belts vs. Blades: the Binary Bind in Iron Age Mortuary Contexts in Southwest Germany. Journal of Bakka, Egil Archaeological Method and Theory 23(3):832-853, https://doi.org/10.1007/s10816-016-9289-8.

1993 Gauselfunnet og bakgrunnen for det. I Minneskrift Egil Bakka, redigert av Bergljot Solberg, s. 248-304. Arkeologiske skrifter Historisk Museum, vol. 7. Historisk museum Universitetet i Bergen, Bergen.

Bender Jørgensen, Lise

1986 Forhistoriske textiler i Skandinavien. Nordiske Fortidsminder Serie B bind 9. Det Kongelige Nordiske Oldskriftselskab, København.

2005 Textiles of Seafaring: an Introduction to an Interdisciplinary Research Project. I Northern Archaeological Textiles. Nesat VII. Textile Symposium in Edinburgh, 5th-7th May 1999, redigert av Frances Pritchard og John Peter Wild, s. 65-69. Oxbow Books, Oxford.

2012 The Introduction of sails to Scandinavia: Raw materials, labour and land. I N-TAG TEN. Proceedings of the 10th Nordic TAG Conference at Stiklestad, Norway 2009, redigert av Ragnhild Berge, Marek E. Jasinski og Kalle Sognnes, s. 173-181. BAR International Series, vol. 2399. Archaeopress, Oxford.

Bertelsen, Reidar, Arnvid Lillehammer og Jenny-Rita Næss (red.)

1987 Were they all men? An examination of sex roles in prehistoric society : acts from a workshop held at Utstein kloster, Rogaland 2.-4. november 1979 (NAM-forskningsseminar nr 1). AmS-Varia, vol. 17. Arkeologisk museum i Stavanger, Stavanger.

Beyer, Harald og Edvard Beyer

1970 Norsk litteraturhistorie. Aschehoug, Oslo.

Brink, Stefan

2012 Vikingarnas slavar. Den nordiska träldomen under yngre järnålder och äldsta medeltid. Atlantis, Stockholm.

Brumfiel, Elizabeth M. og Cynthia Robin

2008 Gender, Household, and Society: An Introduction. Archeological papers of the American Anthropological Association 18(1):1-16, https://doi.org/10.1111/j.1551-8248.2008.00001.x.

Butler, Judith

1999 Gender Trouble. Feminism and the Subversion of Identity. Routledge, New York.

Bødal, Sigmund Matias

1998 Vik i Sogn 750-1030. Lokalsamfunn med overregionale kontakter. Upublisert hovedfagsoppgave i arkeologi med vekt på Norden. Universitetet i Bergen, Bergen.

Bødal, Sigmund Matias

2000 Vik og Sogn i tida kring førre årtusenskiftet. Vik historielag Arrbok 7(2000):42-60.

Conkey, Margaret W. og Janet D. Spector

1984 Archaeology and the Study of Gender. Advances in Archaeological Method and Theory

7(1984):1-38, https://doi.org/10.1016/B978-0-12-003107-8.50006-2.

Dommasnes, Liv Helga

1976 Yngre jernalder i Sogn. Forsøk på sosial rekonstruksjon. Upublisert magistergradsavhandling. Universitetet i Bergen, Bergen.

1979 Et gravmateriale fra yngre jernalder brukt til å belyse kvinners stilling. Viking 42:95-114. 
1982 Late Iron Age in Western Norway. Female Roles and Ranks as Deduced from an Analysis of Burial Customs. Norwegian Archaeological Review 15(1):70-84.

2017 Om hvordan vestlendingen ble viking. Arbok for Universitetsmuseet i Bergen 2017:17-22.

Dommasnes, Liv Helga og Else J. Kleppe (red.)

1985 K.A.N. Kvinner $i$ Arkeologi i Norge, vol. 1. K.A.N, Bergen.

Dommasnes, Liv Helga, Tove Hjørungdal, Sandra Montón-Subías, Margarita Sánchez Romero

og Nancy L. Wicker

2010 Situating Gender in European Archaeologies. Archaeolingua Series Minor. Budapest.

Dommasnes, Liv Helga og Alf Tore Hommedal

2016 One thousand years of tradition and change on two West-Norwegian farms. I The farm as a social arena, redigert av Liv Helga Dommasnes, Doris Gutsmiedl-Schümann og Alf Tore Hommedal, s. 127-169. Waxmann Verlag, Münster.

Dommasnes, Liv Helga og Sandra Montón Subías

2012 European Gender Archaeologies in Historical Perspective. European Journal of Archaeology 15(3):367-391.

Enright, Michael J.

1996 Lady with a Mead Cup. Ritual, prophesy and lordship in the European Warband from La Téne to the Viking Age. Four Courts Press, Dublin.

FemArc

2018 FemArc Netzwerk archäologisch arbeitender Frauen e.v. Elektronisk dokument, https://www. femarc.de/, besøkt 4. september 2018.

Fett, Eva og Per Fett

1951 Det førhistoriske Vik. I Bygdabok for Vik $i$ Sogn, redigert av Olav Hoprekstad, s. 52-138. Boktrykk L/L, Bergen.

Fett, Per

1944 Om Færvollane og om beinkammar og gravflokkar. Viking 8:151-168.

Foote, Peter G. og David M. Wilson

1970 The Viking Achievement. The society and culture of early medieval Scandinavia. Sigdwick \& Jackson, London.

Fries, Jana Esther, Ulrike Rambuscheck og Gisela Schulte Dornberg (red.)

2007 Science oder Fiction? Geschlechterrollen in archäologischen Lebensbilden. Frauen - Forschung - Archäeologie, vol. 7. Waxmann, Münster.

Giddens, Anthony

1997 Sociology. Polity Press, Cambridge.

Gilchrist, Roberta

1999 Gender and Archaeology. Contesting the past. Routledge, London.

Gutsmiedl-Schümann, Doris

2014 Vom kleinen Mädchen zur jungen Frau. Rekonstruktionen von Lebensabschnitten weiblicher subadulter Individuen aufgrund von archäologischen Funden aus merowingerzeitlichen Gräbern der Münchner Schotterebene. I Mädchen im Altertum/Girls in Antiquity, redigert av Susanne Moraw og Anna Kieburg, s. 417-429. Frauen - Forschung - Archäologie, vol. 11. Waxmann, Münster.

Grágás. Islcendernes Lovbog i Fristatens Tid, udgivet efter det kongelige Bibliotheks Haandskrift. 1852. Brødrene Berlings Bogtrykkeri, København. Gjenopptrykt under tittelen Grágás. Konungsbók. 1974, Odense Universitetsforlag, Odense.

Grønnesby, Geir og Aina Heen-Pettersen

2015 Gården i yngre jernalder - et spørsmål om erkjennelse? Belyst ved utgravningen av et yngre jernalders gårdstun på Ranheim. Viking 78:169-188. 
Hanisch, Morten

2001 Gravritualene - fortellinger om ære? - et nytt perspektiv på vestnorsk gravmateriale fra romertid og folkevandringstid. Upublisert hovedoppgave. Arkeologisk institutt, Universitetet i Bergen. Bergen.

Harding, Sandra

1986 The Science Question in Feminism. Cornell University Press, Ithaca.

1991 Whose Science? Whose Knowledge? Thinking from Women's Lives. Cornell University Press, Ithaca.

1998 Is Science Multicultural? Postcolonialisms, Feminisms, and Epistemologies. Indiana University Press, Bloomington.

2004 The Feminist Standpoint Reader. Intellectual and Political Controversies. Routledge, New York. Hartsock, Nancy C. M.

1998 The Feminist Standpoint Revisited and Other Essays. Westview Press, Oxford.

Hedeager, Lotte

2011 Iron Age Myth and Materiality. An Archaeology of Scandinavia AD 400-1000. Routledge, London.

Heide, Eldar

2006 Spinning seidr. I Old Norse religion in long-term perspectives, redigert av Anders Andrén,

Helle, Knut Kristina Jennbert og Catharina Raudvere, s. 164-170. Nordic Academic Press, Lund.

2001 Gulatinget og Gulatingslova. Skald, Leikanger.

Hellesøe, Hege Presttun

2006 Båtgravene i Nordfjord. Upublisert hovedfagsoppgave i arkeologi. Universitetet i Bergen, Bergen.

Helms, Mary W.

1998 Access to origins. Affines, Ancestors and Aristocrats. University of Texas Press, Austin.

Herschend, Frands

1993 The Origin of the Hall in Southern Scandinavia. Tor 25:175-199.

Iversen, Tore

1997 Trelldommen. Norsk slaveri i middelalderen. Historisk institutt, Skrifter, vol. 1. Universitetet i Bergen, Bergen.

Jacobsen, Camilla

2008 En arkeologisk analyse av gravmateriale fra Sogn og Fjordane. Upublisert mastergrad i arkeologi. Universitetet i Bergen, Bergen.

Jondell, Erik

1974 Vikingatidens balansvågar i Norge. C-1-uppsats i arkeologi, särskilt nordeuropeisk. Uppsala VT 1974, Uppsala Universitet, Uppsala.

Jørgensen, Lars og Anne Nørgård Jørgensen

1997 Nørre Sandgård Vest. A Cemetery from the 6th-8th centuries on Bornholm. Nordiske Fortidsminder Serie B, vol. 14. Det Kongelige Nordiske Oldskriftselskab, København.

Kaland, Sigrid

2009 Noen kritiske spørsmål til drakt og nøkler hos vikingtidens husfruer. I Motstrøms - arkeologiske artikler. Venneskrift til Jenny-Rita, redigert av Liv Helga Dommasnes, Peter Emil Kaland, Sigrid H. Kaland, Else Johansen Kleppe, Arne J. Larsen og Gro Mandt, s. 57-71. Bergen Museums skrifter, vol. 29. Bergen museum, Bergen.

Karlisch, Sigrun M., Sibylle Kästner og Eva-Maria Martens (red.)

1997 Von Knochenmann zur Menschenfrau. Feministische Theorie und Archäologische Praxis. Agenda Verlag, Münster. 
Koch, Ursula

1997 Die Hiearchie der Frauen in Merowingischer Zeit, beobachtet in Pledesheim (Kr. Ludwigsburg) und Klepsau (Hohenlohekreis). I Königin, Klosterfrau, Bäuerin. Frauen im Frühmittelalter, redigert av Helga Brandt og Julia K. Koch, s. 29-54. Waxmann Verlag GmbH, Münster.

Kristoffersen, Siv

2000 Sverd og spenne. Dyreornamentikk og sosial kontekst. Studia Humanitatis Bergensia, vol. 13. Høyskoleforlaget, Kristiansand.

Kvamme, Mons

1997 Rapport fra pollenanalytiske undersøkelser på Vereide 1991/1992. I Tradisjon og handling $i$ førkristen vestnorsk gravskikk. Undersøkelser på et gravfelt på Vereide i Gloppen, Sogn og Fjordane, redigert av Liv Helga Dommasnes, s. 225-248. Arkeologiske rapporter, vol. 21. Arkeologisk institutt, Universitetet i Bergen, Bergen.

Lesick, Kurtis S.

1997 Re-engendering gender: some theoretical and methodological concerns on a burgeoning archaeological pursuit. I Invisible people Writing gender and childhood into European Archaeology, redigert av Jenny Moore og Eleanor Scott, s. 31-41. Leicester University Press, London.

Lidén, Hans Emil

1996 Kristendom og kirkebygging på Vestlandet i tidlig middelalder - et eksempel fra Vik. Pridlao 13(3):54-57.

Liestøl, Knut

1929 Upphavet til den islendske cettesaga. Instituttet for sammenlignende kulturforskning. Serie A: Forelesninger. Xa. Aschehoug, Oslo.

Loftsgarden, Kjetil, Morten Ramstad og Frans-Arne Stylegar

2017 The skeid and other assemblies in the Norwegian «Mountain Land». I Viking Age

Transformations.Trade, Craft and Resources in Western Scandinavia, redigert av Zanette T.

Glørstad og Kjetil Loftsgarden, s. 232-249. Routledge, London.

Lukesova, Hana, Adrià Salvador Palau og Bodil Holst

2017 Identifying plant fibre textiles from Norwegian Merovingian Period and Viking Age graves: The Late iron Age Collection of the University of Bergen. Journal of Archaeological Science Reports 13:281-285.

Mehl, Ingvild Kristine og Kari Loe Hjelle

2016 From deciduous forest to open landscape: application of new approaches to help understand cultural landscape development in western Norway. Vegetation History and Archaeobotany 25(2):153-176, https://doi.org/10.1007/s00334-015-0539-6.

Mortensen, Mona

1993 Stedje, gnr. 64, Sogndal kommune, Sogn og Fjordane. Innberetning, bosetningsspor fra jernalderen. Universitetsmuseet i Bergen, topografisk arkiv, Bergen.

Myhre, Bjørn og Ingvild Øye

2002 Norges landbrukshistorie, Band I. 4000 f.Kr-1350 e.Kr. Jorda blir levevei. Det Norske Samlaget, Oslo.

Nissen Meyer, Eva

1935 Relieffspenner i Norden. Bergen Museums Årbok 1934, Historisk-Antikvarisk rekke, vol. 4. Bergen museum, Bergen.

Nordal, Sigurđur

1953 Sagalitteraturen. I Nordisk Kultur VIII. Litteraturhistorie, B. Norge og Island, redigert av Otto von Friesen, s. 180-274. Bonnier, Stockholm.

1957 The Historical Element in the Icelandic Family Sagas : the fifteenth W.P. Ker Memorial Lecture delivered in the University of Glasgow 19th May, 1954. The W.P. Ker Memorial Lectures, vol. 15. Jackson Son \& Co, Glasgow. 
Petersen, Jan

1940 British Antiquities of the Viking Period, found in Norway. Viking Antiquities in Great Britain and Ireland, vol. V. Aschehoug, Oslo.

1951 Vikingetidens redskaper. Skrifter utgitt av Det Norske Videnskaps-akademi i Oslo II. HistoriskFilosofisk Klasse 1951(4). Dybwad, Oslo.

Pilø, Lars

1989 Den førromerske jernalder i Vestnorge. Et kulturhistorisk tolkningsforsøk. Upublisert hovedfagsoppgave i arkeologi. Universitetet i Bergen, Bergen.

Price, Neil S.

2002 The Viking way. Religion and War in late Iron Age Scandinavia. Uppsala University, Uppsala.

Polanyi, Michael

1966 The Tacit Dimension. Routledge and Kegan Paul, London.

Rabben, Anders M.

2002 Med vevsverd og stekepanne. Tekstilredskaper og kjøkkenredskaper i vestnorske mannsgraver fra yngre jernalder. Upublisert hovedfagsoppgave i arkeologi. Universitetet i Bergen, Bergen.

Ramstad, Morten

2011 Bjørkum. Et innblikk i nye økonomiske og sosiale strukturer i tidlig vikingtid. RISS 2:40-53.

Ringstad, Bjørn

1987 Vestlandets største gravminner. Et forsøk på lokalisering av forhistoriske maktsentra. Avhandling for magistergraden i arkeologi, Bergen.

Ryle, Gilbert

1949 The Concept of Mind. Penguin Books Ltd., Harmondsworth.

Sanday, Peggy R.

1974 Female Status in the Public Domain. I Woman, Culture \& Society, redigert av Michelle Zimbalist Rosaldo og Louise Lamphere, s. 189-207. Stanford University Press, Stanford.

Skre, Dagfinn

1997 Haug over grav. Hva betyr gravhaugene? I Middelalderens symboler, redigert av Ann Christensson, Else Mundal og Ingvild Øye, s. 37-52. Kulturtekster, vol. 11. Senter for europeiske kulturstudier, Bergen.

Solberg, Bergljot

1985 Social Status in the Merovingian and Viking Periods in Norway from Archaeological and Historical Sources. Norwegian Archaeological Review 18(1-2):61-76.

Stalsberg, Anne

1996 Varangian women in old Rus: Who were they? K.A.N. Kvinner i Arkeologi i Norge 21:83-102.

Storli, Inger

2006 Hålogaland før rikssamlingen. Politiske prosesser i perioden 200-900 e.Kr. Instituttet for sammenlignende kulturforskning, Serie B, Skrifter, vol. 123. Novus forlag, Oslo.

Straume, Eldrid

1962 Nordfjord i eldre jernalder. Årbok for Universitetet i Bergen. Humanistisk Serie 1961, vol. 4. Norwegian Universities Press, Bergen.

Sweely, Tracy L.

1999 Manifesting Power. Gender and the interpretation of power in archaeology. Routledge, London. Sørensen, Preben Meulengracht

1993 Fortcelling og cere. Studier i Islendingesagaerne. Aarhus universitetsforlag. Aarhus.

Torreira, Lourdes Prados (red.), Clara López Ruis og Javier Parra Camazho

2012 La Arqueología funeraria desde una perspectiva de género. UAM Ediciones. Servicio de Publicaciones de la Universidad Autónoma de Madrid, Madrid.

Unimus

2018 Universitetsmuseenes arkeologiske gjenstandssamlinger. Elektronisk dokument, http://www. unimus.no/arkeologi/forskning/index.php, besøkt 19. januar 2018 og 5. august 2018. 
Wallén, Per-Edwin, E. A. Virtanen, Stig Iuul og Rigmor Frimannslund

1981 Husfru. I Kulturhistorisk leksikon for nordisk middelalder, bind VII, fotografisk opptrykk etter 1. utgave 1956-68, redigert av Georg Rona, s. 134-137. Rosenkilde og Bagger, København.

Ørsnes, Mogens

1966 Form og stil i Sydskandinaviens Yngre Germanske Jernalder. Nationalmuseets Skrifter. Arkæologisk-historisk række, vol. 11. Nationalmuseet, København.

Øye, Ingvild

2011 Textile-production Equipment. I Things from the Town. Artefacts and Inhabitants in Viking-Age Kaupang, redigert av Dagfinn Skre, s. 339-372. Kaupang Excavation Project Publication Series, vol. 3. Aarhus University Press, Århus.

2016a Technology and textile production from the Viking Age and the Middle Ages: Norwegian cases. I Textiles and the Medieval Economy. Production, trade and consumption of textiles 8th-16th centuries, redigert av Angela Ling Huang og Carsten Jahnke, s. 41-63. Ancient Textiles Series, vol. 16. Oxbow Books, Oxford.

2016b When did weaving become a male profession? Danish Journal of Archaeology 5(1-2):34-51, https://doi.org/10.1080/21662282.2016.1245970.

Åstveit, Leif Inge og Anja Sveinsdatter Melvær

2013 Arkeologiske undersøkelser av aktivitets-og bosetningsspor fra jernalder/middelalder på Sæbø gnr/bnr 1/24, Vik, Sogn og Fjordane. Rapport i Universitetsmuseet i Bergen, Avdeling for kulturhistorie, Topografisk arkiv. Bergen. 